\title{
An Inside Job: Applications of Intracellular Single Domain Antibodies
}

\author{
Eline Soetens ${ }^{1,2}$, Marlies Ballegeer ${ }^{1,2} \mathbb{D}$ and Xavier Saelens $1,2, * \mathbb{D}$ \\ 1 VIB-UGent Center for Medical Biotechnology, VIB, B-9052 Ghent, Belgium; eline.soetens@vib-ugent.be (E.S.); \\ marlies.ballegeer@vib-ugent.be (M.B.) \\ 2 Department of Biochemistry and Microbiology, Ghent University, B-9000 Ghent, Belgium \\ * Correspondence: xavier.saelens@vib-ugent.be
}

Received: 20 November 2020; Accepted: 10 December 2020; Published: 12 December 2020

\begin{abstract}
Sera of camelid species contain a special kind of antibody that consists only of heavy chains. The variable antigen binding domain of these heavy chain antibodies can be expressed as a separate entity, called a single domain antibody that is characterized by its small size, high solubility and oftentimes exceptional stability. Because of this, most single domain antibodies fold correctly when expressed in the reducing environment of the cytoplasm, and thereby retain their antigen binding specificity. Single domain antibodies can thus be used to target a broad range of intracellular proteins. Such intracellular single domain antibodies are also known as intrabodies, and have proven to be highly useful tools for basic research by allowing visualization, disruption and even targeted degradation of intracellular proteins. Furthermore, intrabodies can be used to uncover prospective new therapeutic targets and have the potential to be applied in therapeutic settings in the future. In this review we provide a brief overview of recent advances in the field of intracellular single domain antibodies, focusing on their use as research tools and potential therapeutic applications. Special attention is given to the available methods that allow delivery of single domain antibodies into cells.
\end{abstract}

Keywords: single domain antibody; intrabody; delivery methods; therapy; research tool

\section{Introduction}

In 1993, a serendipitous discovery that led to the identification of a new type of antibody in the sera of camelid species was reported [1]. It was demonstrated that the serum of these mammals not only contains classical immunoglobulins (IgGs), but also a second type of antibody that consists only of heavy chains. These so called heavy chain antibodies (HCAbs) make up 50-80\% of the total serum IgG amount in camels and 10-25\% in South-American camelids [2], suggesting that they play an important role in the humoral immune response of these animals. Similar alternatives to classical antibodies, named new antigen receptor (IgNAR) antibodies, were also found in the sera of some cartilaginous fish, such as nurse sharks and wobbegong sharks [3,4]. Although the sequences of these ancestral IgNAR antibodies differ significantly from camelid HCAbs, their structures show a remarkable resemblance, which points towards convergent evolution $[4,5]$. In the wake of the discovery of HCAbs in camelid sera, it was soon realized that the HCAb variable domain ( $\mathrm{VHH}$ ) could be expressed as a separate protein fragment, while retaining full antigen binding capacity [6]. VHHs have a size of about $2.5 \mathrm{~nm}$ in diameter and $4 \mathrm{~nm}$ in length and are the smallest natural antigen-binding entities known to date [7] (Figure 1). 


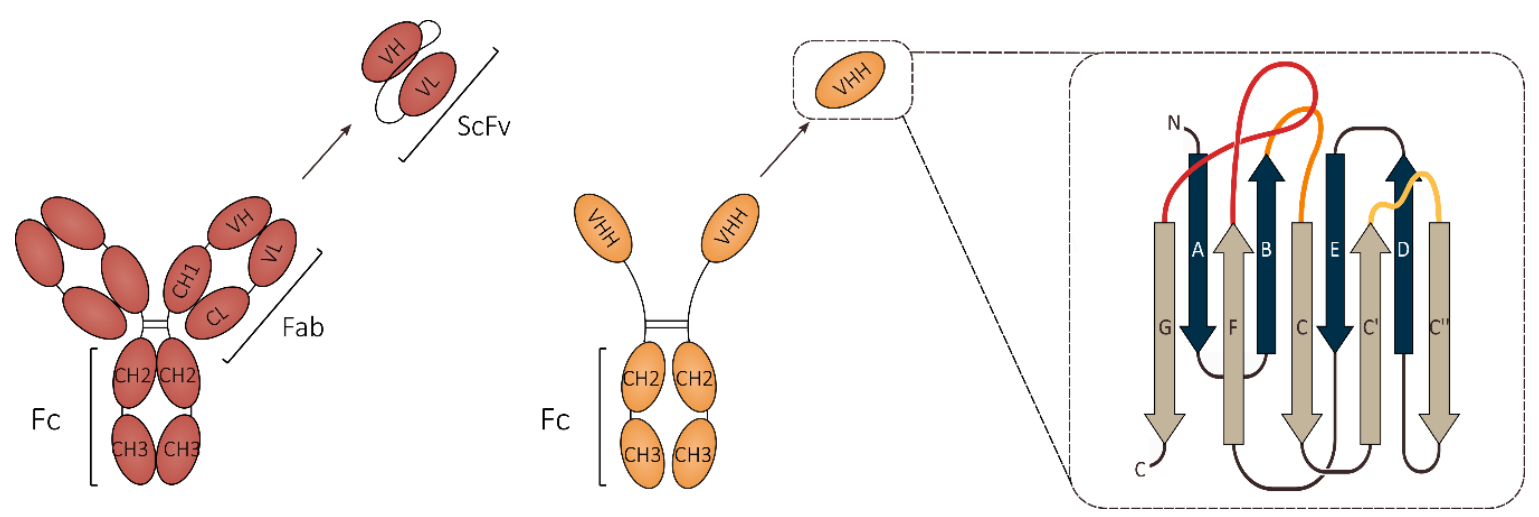

Figure 1. Schematic representation of a conventional IgG antibody (left) and a camelid heavy chain antibody (middle), with their respective smallest antigen-binding formats: a single chain variable fragment ( $\mathrm{ScFvs}$ ) and a single domain antibody ( $\mathrm{VHH})$. To the right, a folded $\mathrm{VHH}$ domain is schematically shown with CDR 1, 2 and 3 indicated in orange, yellow and red, respectively. $\mathrm{CH}$ : heavy chain constant domain; CL: light chain constant domain; VH: heavy chain variable domain; VL: light chain variable domain; $\mathrm{VHH}$ : variable domain of heavy chain antibody.

Heavy chain antibodies lack light chains, as well as the first constant domain (CH1). To compensate for these differences, the variable domains of HCAbs have adopted distinct structural features. Firstly, the hallmark residues in framework region 2 (FR2) of the $\mathrm{VHH}$, which account for the interaction with the light chain in classical antibodies, have been replaced by more hydrophilic residues [8-11]. Indeed, it has been demonstrated that swapping the corresponding hydrophobic residues in a human heavy chain variable domain $(\mathrm{VH})$ for smaller and more hydrophilic ones, promotes solubility and avoids aggregation [12]. The paratope of VHHs consists of three complementarity determining regions (CDRs) compared to six in classical antibodies. The adjacent CDR loops of the heavy and light chain variable domains in classical antibodies form a paratope surface of 600-900 $\AA^{2}$. VHHs make up for the reduced number of CDR loops by increasing their length, in particular CDR3 (on average two to four amino acids longer compared to human IgG [9]), resulting in an average paratope surface of 600-800 $\AA^{2}$ [13]. As a longer CDR3 loop may be entropically unfavorable for epitope binding, camel-derived VHHs often contain an additional interloop cysteine bridge between CDR1 and CDR3, effectively constraining the movement of the CDR3 loop [14]. This disulfide bond is notably less common in llama VHHs, which can be explained by the shorter CDRs present in these VHHs [9-11]. Structural differences between the variable domains of classical antibodies and HCAbs can explain why these two antibody variants differ in their target antigen preference. Classical antibodies typically adopt a concave paratope surface, making them more prone to bind to protruding or flat surfaces. On the other hand, the prolate shape of VHHs combined with their small size makes them very suitable for binding clefts on the protein surface, such as enzymatic sites [13].

VHH coding sequences are usually isolated from immunized animals, after which specific binders are enriched by robust selection methods such as phage display, although other types of VHH libraries (BOX 1) and selection methods (BOX 2) have also been successfully used to identify high affinity binders. Several properties of VHHs have made them attractive research tools and explain why they have been extensively used in many labs in the almost thirty years since their discovery. The classical antibody counterpart of VHHs are called single-chain variable fragments (scFvs) and are made up of the heavy and light chain variable domains of classical immunoglobulins, connected by a flexible peptide linker. Over the years, these scFvs have also proven their value as research tools [15], yet the main advantage VHHs hold over scFvs is that they only consist of one domain, which makes them more convenient for cloning and genetic engineering. Additionally, VHHs with affinities in the nanomolar to picomolar range can be routinely obtained (BOX 2) and can even be improved further by in vitro affinity maturation techniques that are based on error prone PCR or Ala-scanning [16,17]. Lastly, 
VHHs are usually very stable, being able to resist chemical (e.g., $7 \mathrm{M}$ guanidinium chloride or $10 \mathrm{M}$ urea) and thermal denaturation ( $\mathrm{T}_{\mathrm{m}}$ is on average $60^{\circ} \mathrm{C}$ or higher) [18].

\section{Single Domain Antibodies as Intrabodies}

The term intrabodies is derived from intracellular and antibody, and refers to antibodies that can be used to target selected proteins inside the cell. Originally, intrabodies mainly existed as single-chain variable fragments and were seen as a promising new class of active molecules that could be used for treatment of diseases such as AIDS [19]. Although there are examples where scFvs have been used successfully as intrabodies, the reducing environment of the cytoplasm, in which the intra-domain cysteine bridges fail to form, often prohibits their proper folding [20]. Some proposed solutions for this problem include expression of the scFvs as fusion proteins, e.g., with the E. coli maltose binding protein [21], design of scFvs that lack disulfide bridges [22] and grafting of CDRs onto stable scFvs frameworks [23]. Despite these possibilities, the inherent stability of single domain antibodies makes them much more suitable for intracellular expression compared to their scFvs counterparts. Indeed, VHHs in which both cysteine residues were replaced by serine residues were still able to effectively bind their cytosolic targets with only a 2-fold reduction in affinity, as was shown for a VHH targeting glial fibrillary acidic protein whose affinity decreased from $5.6 \mathrm{nM}$ to $12 \mathrm{nM}$ upon mutation of the cysteine residues [24]. It is worth noting that VHHs containing an additional disulfide bridge, which is common in camel VHHs but also occurs in VHHs derived from other species [9-11,14], are more likely to fail to fold properly in the cytoplasm and may thus be less suitable for use as intrabodies [25]. Nonetheless, the single domain nature of VHHs makes them decidedly easier to select and engineer, and allows targeting of epitopes that would not be available to scFvs.

Usually, intrabodies are directly expressed inside the cell, yet other delivery methods that facilitate transport of the VHHs across the cell membrane are possible. Once inside the cell, the small size of VHHs allows them to diffuse freely through the nuclear pore complexes, although they can also be specifically targeted towards the nucleus by addition of a nuclear localization signal (NLS) [26]. Furthermore, VHHs can be targeted to the lumen of the endoplasmic reticulum (ER) by fusion with a secretory signal peptide combined with the KDEL ER-retention sequence $[27,28]$. In this way, VHHs are retained in the ER compartment together with their antigen. Using this method for targeting of secreted or membrane proteins allows modulation of the secretome of the cell, from the inside out.

The propensity of VHHs to bind cleft-like structures makes them ideal for the binding of active sites of enzymes. Intracellular expression of these VHHs opens up a whole new range of potential therapeutic targets, which were previously inaccessible using traditional monoclonal antibody $(\mathrm{mAb})$ therapy. Moreover, intracellular VHHs are also very well suited to study protein function, because their target specificity can be combined with coupling of the $\mathrm{VHH}$ to a functional group, such as a proteasomal degradation tag, which allows selective degradation of the target protein. In the next section the advantages and disadvantages of available methods for delivery of VHHs into the cell interior are discussed.

\section{Delivery Methods for Intracellular Single Domain Antibodies}

The plasma membrane is a barrier that prevents the diffusion of intracellular macromolecules into the cell surrounding medium and, vice versa, the spontaneous uptake of exogenous macromolecules. In order to deliver macromolecules, such as VHHs, to the cytoplasm of the cell, the plasma membrane thus needs to be transiently breached. There are two main methods to achieve this: extracellular addition of purified proteins, often combined with a physical plasma membrane disturbing procedure, or delivery of a genetic element into the target cell cytoplasm or nucleus, which instructs for the intracellular expression of the VHH (Figure 2). 


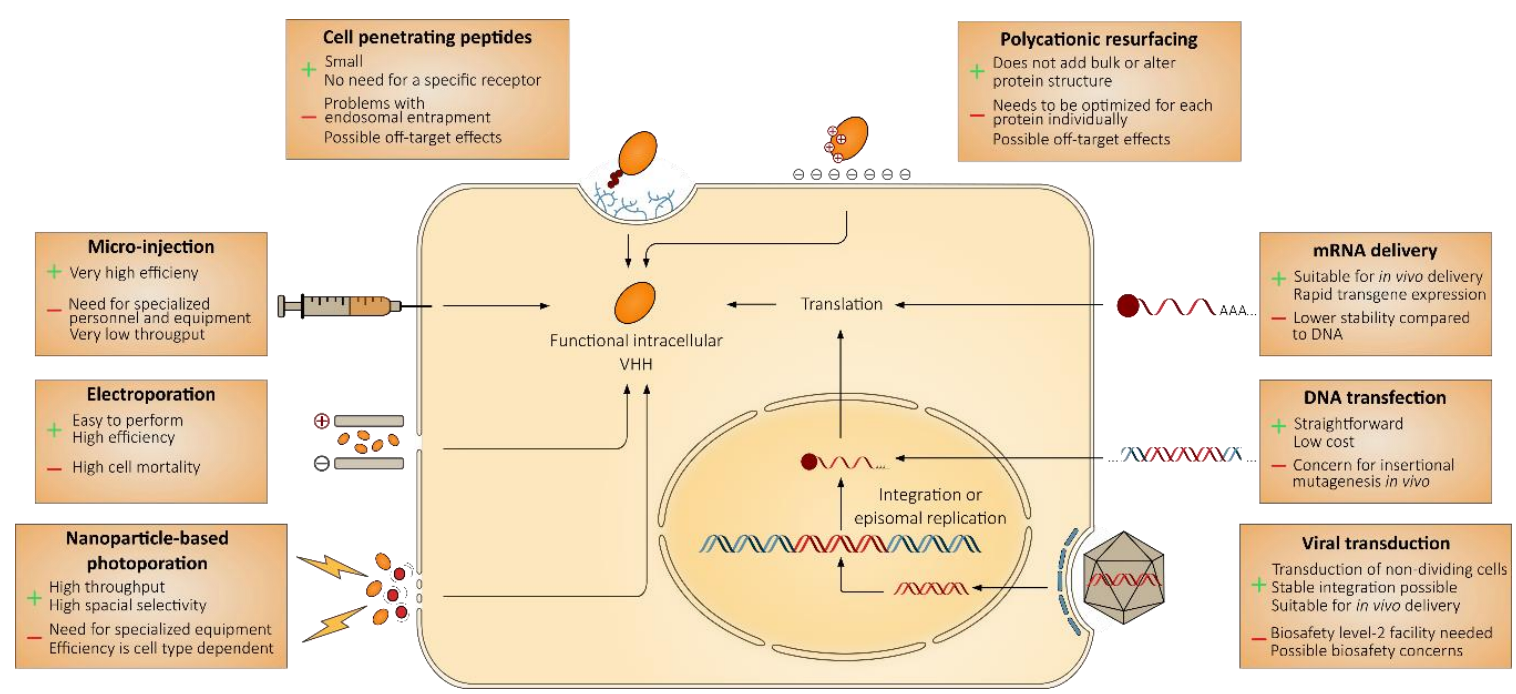

Figure 2. Schematic diagram of methods that are available to deliver VHHs into the cytosol of the cell. Methods such as micro-injection, electroporation and photoporation (left) require (transient) physical disruption of the cell membrane, while coupling to cell penetrating peptides and polycationic resurfacing (top) are based on electrostatic interactions with the cell surface. Expression based methods include mRNA, DNA or viral vector-based delivery processes (right).

\subsection{Microinjection, an Efficient but Low-Troughput Method}

Direct delivery of antibodies in the cytoplasm of the cell was first reported in the 1980s, when it became clear that some monoclonal antibodies remained stable upon microinjection into the cell, and retained their antigen specificity [29-31]. For example, when embryonic fibroblasts isolated from $\mathrm{BALB} / \mathrm{c}$ mice that carry an intact $M x 1$ gene, which codes for an interferon inducible large GTPase with broad antiviral activity, were injected with the Mx1-specific monoclonal antibody 2C12, the cells became very susceptible to subsequent influenza A virus infection. The authors showed that these cells still expressed the $\mathrm{Mx} 1$ protein, yet $\mathrm{mAb} 2 \mathrm{C} 12$ prevented it from exerting its antiviral activity [32]. Microinjection has mostly fallen into disuse due to the high level of skill needed to perform this technique and its low-throughput nature.

\subsection{Electroporation, an Efficient Method Associated with High Cytotoxicity}

Electroporation is a very effective method for delivering proteins into a variety of cells [33]. This physical delivery technique relies on the application of an electric pulse to the cells, which results in a transient rearrangement of the cell membrane, caused by a transient reorientation of bipolar lipid molecules under an intense electric field [34]. This rearrangement results in the formation of hydrophilic pores that last from several milliseconds to seconds and allow macromolecules to cross the cell membrane into the cytosol $[35,36]$. When it comes to antibodies, electroporation was shown to be more efficient compared to different profection reagents, such as ProteoJuice, Bioporter, ab-DeliverIN or Pulsin [37]. However, electroporation is generally accompanied by high cytotoxicity, making it difficult to implement for certain applications [38,39]. As for any technique that includes disruption of the cell membrane, a balance must be found between efficiency and cell viability.

\subsection{Photoporation, a High-Throughput Method with Excellent Spatial Selectivity}

Direct delivery of proteins into the cell can also be achieved by laser-assisted photoporation. By focusing short (femtosecond) high-intensity laser pulses directly on the plasma membrane, transient openings are created through which macromolecules can diffuse into the cytoplasm [40,41]. More recently, it was discovered that the efficacy of this technique could be significantly increased by pre-incubating the cells with sensitizing particles, such as plasmonic gold nanoparticles (AuNPs). Lapotko and others 
have described that excitation of these nanoparticles with short laser pulses, led to the formation of so-called vapor nanobubbles (VNBs) [42-44]. These VNBs are formed when the water surrounding the nanoparticles evaporates due to heating of the AuNPs by the laser pulse. Eventually, the VNBs will seize to expand and collapse again, creating local shockwaves that transiently disrupt the cell membrane. VNB photoporation makes use of lower intensity, more diffuse laser beams, compared to the direct use of laser pulses to disrupt the cell membrane. This allows treatment of a higher number of cells, while maintaining high spatial selectivity [45]. This technique has recently been explored for the delivery of fluorescently labeled VHHs into cells, followed by high resolution imaging. Repeated photoporation of cells with fluorescently labeled VHHs allowed detailed visualization of vimentin structures in live cells [46]. Also using this technique, VHHs directed against GFP, fascin and histone H2A/H2B heterodimers were successfully used for intracellular staining in living HeLa cells [47]. Furthermore, time-lapse imaging showed that cell division and migration, as well as mitochondrial function were not affected after photoporation, indicating the value of VNB photoporation of labeled VHHs for high resolution imaging in live cells.

\subsection{Cell Penetrating Peptide-Coupled Single Domain Antibodies Lead to Receptor Independent Cellular Uptake}

The discovery that a protein can cross the cell membrane was reported simultaneously by the labs of Carl Pabo and Maurice Green, when they realized that the HIV-1 Tat (transactivator of transcription) protein could spontaneously traverse the plasma membrane of mammalian cells when added to the extracellular medium $[48,49]$. Soon thereafter this cell-penetrating property of the Tat protein was attributed to a 12 amino acid residue peptide (GRKKRRQRRRPQ). Moreover, it became clear that fusion of this peptide to other proteins could equally carry them across the cell membrane [50]. This elegant way of delivering proteins into cells was soon explored further and currently, about 1800 cell penetrating peptides (CPPs), which are usually 5-30 amino acid residues long and positively charged at physiological $\mathrm{pH}$, have been described [51]. After the initial enthusiasm surrounding this discovery, it became clear that most proteins that are fused with a CPP remained stuck in the endosomal compartment after uptake by the cell and that the cytosolic distribution observed in earlier studies in many instances could be attributed to a fixation artefact [52,53]. Endosomal retention led the proteins to either be degraded via the lysosomal pathway or eventually recycled back to the cell membrane, meaning they never reached the cytoplasm of the cell. This feature of CPP mediated protein delivery was named the 'endosomal escape problem' [54]. Despite issues with endosomal entrapment, several successful examples of VHH delivery through CPPs have been reported. For example, VHHs directed against the hepatitis $\mathrm{C}$ virus (HCV) NS4B protein were linked to a penetratin CPP, and could reduce viral RNA levels in human hepatoma cells by 1 log value [55]. The use of arginine-rich cyclic CPPs was also demonstrated for the non-endocytic delivery of VHHs targeting proliferating cell nuclear antigen and p53 into living cells [56]. This way, VHHs were delivered directly into the cytoplasm where they were able to bind and even relocate their targets. Lastly, VHHs fused to CPPs have been used for targeting the endothelial growth factor receptor (EGFR). This receptor is overexpressed in many cancer cells, making it an attractive target for therapeutic intervention. VHHs targeting the kinase domain of the EGFR, which is localized in the cytoplasm, as well as EGFR-VHHs coupled to photosensitizers, have led to promising in vitro results in MCF-7 and A431 EGFR overexpressing cell lines, as they significantly reduced cell migration $[57,58]$. One of the main problems concerning the use of CPPs for therapeutic purposes is their lack of cell specificity, which results in a lower effective concentration of the therapeutic at the desired site of action and may also lead to off-target effects [59,60]. However, bio-panning of peptide-displaying phage libraries on cell types or tissues of interest has resulted in the discovery of cell type specific CPPs [61]. 


\subsection{Resurfacing of Single Domain Antibodies Allows Spontaneous Crossing of Cell Membranes without Added Bulk}

Polycationic resurfacing is a technique that has been used to modify the surface charge of proteins in order to increase cell permeability. To achieve this, surface exposed polar residues are replaced by positively charged arginine or lysine residues. The uptake mechanism of these positively charged proteins is most likely based on an electrostatic interaction with surface glycosaminoglycans followed by endocytosis, as was demonstrated for a supercharged +36 GFP variant [62]. Such cationization has been successfully applied for delivery of proteins and monoclonal antibodies into mammalian cells [62-64]. However, modification of surface charge may affect the stability and functionality of proteins. Another downside of polycationic resurfacing is the lack of standardization, meaning that the optimal amino acid substitutions need to be re-evaluated for each separate case. Therefore, in the particular case of VHHs, Bruce et al. have proposed the construction of a well-defined polycationic VHH scaffold, which can be used to graft the CDRs of VHHs that bind an intracellular target of interest [65]. Three previously reported VHHs, targeting GFP, HER2 and $\beta$ lactamase, were chosen for polycationic resurfacing and subsequently examined for their structural integrity and cell penetrating properties. Determination of the $\mathrm{VHH}$ 's structural features using circular dichroism revealed no significant differences between the original and resurfaced $\mathrm{VHHs}$, indicating that polycationic resurfacing does not lead to dramatic structural changes. GFP fusions were used to evaluate the penetration of the resurfaced VHHs into 3T3 cells. Using a flow cytometry based read-out, a concentration dependent intracellular GFP signal could be detected in the case of polycationic resurfaced VHHs, while unaltered VHHs did not enter the cells [65]. In another study, cationic VHHs that target human glial fibrillary acidic protein (GFAP), a specific marker of astrocytes, were shown to be able to cross the blood brain barrier in mice [24]. GFP fusions of these GFAP-VHHs could specifically label astrocytes in murine brain tissue sections and allowed the visualization of murine astrocytes in vivo following intracarotid or intravenous injection. Although these in vivo results are promising and provide possibilities for the use of VHHs in diagnosis and treatment of conditions of the central nervous system, cell membrane crossing VHHs still face the problem of limited tissue penetration and uneven target labeling, issues that will need to be resolved before imaging or therapeutic applications are possible.

\subsection{Delivery by Nucleic Acids, a Straighforward Method that Is Suitable for In Vivo Delivery}

Transfection of plasmids that contain VHH coding sequences is the most straightforward way to express a VHH as an intrabody. Rothbauer et al. demonstrated that GFP targeting VHHs that were expressed intracellularly following transfection of HEK293T cells, could modulate the spectral properties of their target protein [66].

Although recombinant plasmid transfection is very useful in research settings, and has been used frequently in clinical trials to elicit vaccine antigen-specific immune responses, there is some concern that injected plasmid DNA or parts thereof may insert in the genome of somatic cells. A more appropriate carrier for the transient delivery of genetic material into cells may be in vitro transcribed (IVT) RNA. Delivery via mRNA allows a transient and rapid expression of the encoded therapeutic specifically in the target organ, which allows a reduction of the administered dose and minimizes risk of toxicity. The use of mRNA encoded antibody formats has already been demonstrated in the case of extracellular targets for treatment in clinical models of viral infections, such as RSV and HIV-1, as well as for treatment of advanced tumors [67-69]. Zhou et al. demonstrated that transfection of in vitro transcribed nucleoside-modified RNA encoding VHHs led to efficient VHH production in A549 cells as soon as $3 \mathrm{~h}$ post-transfection [70]. Once expressed, the VHHs that target GFP, vimentin or histone deacetylase 6 are able to specifically bind their respective targets and remain present in the cells up to $72 \mathrm{~h}$ after transfection, as demonstrated by immunohistochemistry and western blotting

Another way to deliver a VHH coding sequence into cells is by viral transduction. Lentiviral VHH libraries have been used as a screening method to select for VHHs that can interfere with the replication of several viruses such as influenza A virus (IAV), vesicular stomatitis virus (VSV) and 
porcine reproductive and respiratory syndrome virus (PRRSV) [71,72]. When it comes to the use of VHHs for therapeutic purposes, adeno-associated viruses (AAV) are an appealing way for delivery of the $\mathrm{VHH}$ gene into the cell, as they rely on persistent episomal replication and expression of the encoded cargo [73]. Successful in vivo AAV delivery of an intracellular VHH was demonstrated by Li et al., who investigated the effects of a VHH that targets the phosphorylation site at the cytoplasmic side of ryanodine receptor 2 (RyR2) [74]. Chronic phosphorylation of RyR2 in cardiomyocytes leads to heart failure. Indeed, AAV-9 mediated delivery of the anti-RyR2 VHH in a rat model for ischemic heart failure not only leads to reduced phosphorylation of RyR2, but also normalized myocardium function. It is important to note however, that pre-existing immunity against AAV vectors has been identified in a large part of the population [75].

\section{Therapeutic Potential of Intrabodies}

With over 100 monoclonal antibodies currently approved by the U.S. Food and Drug Administration (FDA), mAbs are the leading therapeutic biopharmaceuticals used worldwide [76]. Still, many targets remain inaccessible to $\mathrm{mAbs}$ and their production costs are substantial [77]. On the contrary, expenses of $\mathrm{VHH}$ production can be kept low by the use of microorganism based expression systems [78]. Furthermore, VHHs can be engineered in different formats to optimize their pharmacokinetic properties [79]. In 2018, the first VHH based therapeutic, caplacizumab, was approved by the EMA for the treatment of acquired thrombotic thrombocytopenic purpura, a rare blood-clotting disease [80]. Several more clinical trials involving VHHs are currently ongoing, yet all of these therapeutics are directed at extracellular targets. Nonetheless, intracellular VHHs have also been shown to have therapeutic potential in several disease areas. In this section, we highlight reports on the use of intracellular VHHs with potential clinical applications, published from 2017 onwards. A comprehensive overview of publications concerning intrabodies with possible therapeutic applications is provided in Table 1.

\subsection{Intrabodies with Therapeutic Potential for Cancer Therapy}

When it comes to the treatment of solid tumors, VHHs may be able to outperform mAbs as their small size allows superior tumor penetration. This results in a higher effective antibody concentration and allows targeting of the entire tumor [81]. It is however important to note that a very high affinity for the antigen may also result in immobilization on the surface of the tumor and failure to penetrate, which is a challenge for both VHHs and mAbs alike. The major downside of using VHHs in cancer therapies is their fast renal clearance, resulting in half-life values of as little as half an hour. However, cell penetrable VHHs can escape this rapid clearance and thereby prolong their therapeutic activity.

The EGFR is abnormally regulated in many cancer cell types. The receptor can be overexpressed or activated without ligand interaction, leading to increased cell proliferation, migration and angiogenesis [82]. Current therapeutics targeting EGFR are either kinase inhibitors or mAbs, such as trastuzumab, that target the extracellular receptor domain, thereby blunting receptor signaling. The main issue with the use of kinase inhibitors as therapeutics remains their off-target effects, while long term treatment with mAbs may lead to selection of non-responding tumor cells $[83,84]$. VHHs have been explored as a new therapeutic to target the EGFR. A VHH that targets the EGFR ectodomain has been demonstrated to prevent the outgrowth of A431 derived solid tumors in a murine xenograft model by inhibiting EGFR signaling [85]. To circumvent the limited efficacy of these VHHs caused by their rapid clearing, Tabtimmai et al. isolated three VHHs, from a humanized camel phage display library, that can cross the cell membrane by linkage to a nona-arginine cell penetrating peptide. These VHHs target the cytosolic tyrosine kinase domain of the EGFR (EGFR-TK) and were approximately 1000-fold more efficient in blocking kinase activity compared to a small compound kinase inhibitor. Furthermore, all three VHHs could significantly lower cell migration of A549 cells without causing cytotoxicity [58].

Pancreatic cancer is extremely difficult to treat and marked by a highly hypoxic tumor environment. Hypoxia induced factor $1 \alpha(\mathrm{HIF}-1 \alpha)$ is one of the main regulators of cell survival under hypoxic 
conditions and has been found to play a central role in tumor progression of pancreatic cancers, making it an interesting therapeutic target [86]. It has been demonstrated that high expression of HIF-1 $\alpha$ can increase resistance of pancreatic tumor cells to the current first line chemotherapeutic gemcitabine and that knock down of HIF-1 $\alpha$ combined with gemcitabine leads to significant synergistic effects $[87,88]$. Use of chemical HIF- $1 \alpha$ inhibitors is associated with indirect off-target effects, while the in vivo use of CRISPR-Cas9 based delivery systems for HIF-1 $\alpha$ knock-out remains challenging [89,90]. $\mathrm{Hu}$ et al. reported the isolation of a HIF-1 $\alpha$ specific $\mathrm{VHH}$ via ribosome display, which was further optimized by in silico guided affinity maturation [91]. Intracellular expression of the HIF-1 $\alpha \mathrm{VHH}$ significantly enhanced gemcitabine cytotoxicity in pancreatic tumor cell lines, making it an interesting candidate for further therapeutic exploration. However, the main challenge for clinical application of intrabodies remains to find efficient and safe ways for their intracellular delivery.

\subsection{Intrabodies as Therapeutic Options for Diseases Caused by Protein Misfolding}

Misfolding and aggregation of $\alpha$-synuclein in the brain is a hallmark of many neurodegenerative diseases. The most prominent of these conditions, Parkinson's disease, is characterized by the presence of intracellular $\alpha$-synuclein aggregates throughout the brain, called Lewy bodies. It has been suggested that neuron toxicity is mainly caused by the soluble $\alpha$-synuclein oligomers, rather than the large insoluble fibrils which are formed at a later stage [92]. This makes soluble $\alpha$-synuclein monomers and oligomers interesting targets for therapeutic intervention in Lewy body disorders. Guilliams et al. characterized two VHHs, derived from an immunized llama, that bind distinct epitopes in the C-terminus of $\alpha$-synuclein [93]. This proved to be an interesting binding site, as the C-terminus of $\alpha$-synuclein is accessible in both its soluble form, as well as in the insoluble fibrils, although binding affinity was reduced upon extensive fibril formation. Next, it was demonstrated that these VHHs, NbSyn2 and NbSyn87, both inhibit the formation of $\alpha$-synuclein fibrils in vitro. Moreover, VHH binding led to a destabilization of $\alpha$-synuclein fibrils and reduced cellular toxicity [94]. In order to increase the efficacy of the $\alpha$-synuclein-specific VHHs, a proteasomal targeting PEST motif was added to the VHH C-terminus, which would allow the VHHs to target monomeric as well as oligomeric $\alpha$-synuclein for proteasomal degradation, effectively preventing fibril formation. Indeed, fusion of NbSyn87 to a PEST motif led to rapid degradation of $\alpha$-synuclein levels in vitro, along with reduced cytotoxicity [95]. In vivo proof-of-concept for the therapeutic treatment of $\alpha$-synuclein aggregation induced neural damage was provided by Chatterjee et al. [96]. A viral vector encoding human $\alpha$-synuclein was injected into the substantia nigra of Sprague-Dawley rats, leading to the formation of Lewy body-like inclusions. Three weeks later, animals were treated with lentiviral vectors encoding NbSyn83-PEST by stereotaxic injection into the substantia nigra. Histological analysis indicated that the treatment led to a two-fold reduction in the presence of $\alpha$-synuclein aggregates compared to saline-treated control animals. Unfortunately, this reduction was also accompanied by an augmented inflammatory response, characterized by increased microglial density. Nevertheless, these studies demonstrate the potential of treating Lewy body diseases, such as Parkinson's disease, with viral vector delivered intracellular $\alpha$-synuclein targeting VHHs.

Another protein misfolding disease is gelsolin amyloidosis, an autosomal dominantly inherited affliction that leads to a plethora of neurological, ophthalmological and dermatological symptoms [97]. A point mutation in the gelsolin protein results in a partial unfolding of the second domain, revealing a cryptic furin cleavage site. Subsequent intracellular cleavage by furin followed by extracellular cleavage by MT1 matrix metalloproteinase (MT1-MMP) leads to the formation of $8 \mathrm{kDa}$ and $5 \mathrm{kDa}$ gelsolin plasma fragments, which are prone to aggregation. Verhelle et al. aimed at preventing the formation of these gelsolin fragments using a bispecific $\mathrm{VHH}$ construct that is able to protect gelsolin from both cleavage by furin and MT1-MMP [98]. Both VHHs were separated by a Gly-Ser linker and an MT1-MMP sensitive peptide. Following injection of the AAV-Nb11-FAF 1 vector in the retro orbital plexus of AGel mice, the VHH construct was detectibly expressed in the plasma up to 3-months post injection, and was associated with reduced cleavage of mutant gelsolin fragments and concomitant significantly improved muscle contractions. 
The above studies underline the utility of VHHs as therapeutics in protein misfolding diseases. They can be armed with effector functions and can target specific protein domains, all while maintaining their binding abilities in the cytosol.

\subsection{Intrabodies as Potential Therapeutics against Live-Stock Viruses}

Porcine reproductive and respiratory syndrome virus (PRRSV) is an enveloped positive stranded RNA virus which causes major economic losses in the pig industry worldwide [99-101]. Although the emergence of this virus dates back to the 1980s, outbreaks still cannot be controlled effectively due to its rapid evolution and frequent outbreaks of highly pathogenic strains [102]. Because of its crucial role in the viral life cycle, Liu et al. have chosen PRRSV non-structural protein 4 (Nsp4) as a potential new therapeutic target [103]. Three Nsp4 binding VHHs were isolated from an immune library by phage display and their coding sequences were subsequently delivered into Marc-145 cells by lentiviral transduction. Two of these stable cell lines, producing $\mathrm{Nb} 41$ and $\mathrm{Nb} 43$ were shown to be resistant to PRRSV replication. The same research group also isolated VHHs against a second PRRSV non-structural protein, Nsp9 [104]. One particular VHH candidate, Nb9, was fused to a Tat-CPP and shown to be successfully delivered into porcine alveolar macrophages while retaining its anti-PRRSV abilities [105]. Next, a broader lentiviral-based screen was set up to identify PRRSV neutralizing VHHs [72]. In this study, the $\mathrm{VHH}$ repertoire from a naïve camel VHH library was delivered into Marc-145 cells, which were subsequently screened for their PRRSV resistance. This screen delivered three promising candidates, which were able to suppress PRRSV replication when expressed intracellularly. One candidate, $\mathrm{Nb}$, which the authors propose targets the viral glycoprotein, was also able to suppress PRRSV infection when delivered into Marc-145 cells via fusion with an NLS-A cell penetrating peptide. Taken together, these studies demonstrate that intracellularly expressed VHHs may be further developed as attractive new therapeutics against PRRSV.

Another virus that poses a threat to live-stock animals is bovine viral diarrhea virus (BVDV). BVDV is a positive stranded RNA virus that belongs to the Pestivirus genus. Infections with BVDV cause worldwide economic losses in the cattle industry and so far there is no effective treatment available [106]. Recently, the use of intracellular VHHs was also investigated as a potential therapeutic to control BDV outbreaks. Duan et al. chose the highly conserved BVDV non-structural protein 5B (NS5B), which functions as an RNA-dependent RNA-polymerase, as a target [107]. After immunization of a camel with NS5B, specific VHHs were enriched by three consecutive rounds of bio-panning. Eventually, after characterization of binding specificity and selection based on CDR3 variability, three VHHs were retained. These were introduced in MBCK cells via lentiviral transduction and tested for their ability to protect the cells from BVDV infection. One candidate, $\mathrm{Nb1}$, was able to suppress BVDV infection when expressed intracellularly. The above studies demonstrate that VHHs can not only be used as therapeutics in the clinic, but can also aid in the control of infectious diseases that threaten live-stock animals. 
Table 1. Overview of intracellular VHHs with possible therapeutic applications.

\begin{tabular}{|c|c|c|c|c|c|c|}
\hline VHH Identifier & Target & Indications & Modification & Delivery & Outcome & References \\
\hline \multicolumn{7}{|c|}{ Cancer Therapies } \\
\hline $\begin{array}{c}\text { R9-VH18, R9-VHH35, } \\
\text { R9-VH36 }\end{array}$ & EGFR-TK & $\begin{array}{l}\text { Non-small cell lung } \\
\text { cancer and many } \\
\text { other cancer types }\end{array}$ & l & $\begin{array}{c}\text { Nona-arginin CPP } \\
\text { (R9) }\end{array}$ & $\begin{array}{l}\text { Cell penetrable VHHs were } \\
\text { approximately } 1000 \text {-fold more } \\
\text { efficient than conventional tyrosine } \\
\text { kinase (TK) inhibitors in in vitro } \\
\text { assays. R9-VH18 and R9-VH36 also } \\
\text { significantly reduced A549 cell } \\
\text { motility compared to TK inhibitors. }\end{array}$ & {$[58]$} \\
\hline VHH212 & HIF- $1 \alpha$ & $\begin{array}{l}\text { Pancreatic ductal } \\
\text { adenocarcinoma } \\
\text { (PDAC) tumors }\end{array}$ & / & Transient transfection & $\begin{array}{l}\text { Intracellular expression of VHH212 } \\
\text { could significantly lower the IC50 of } \\
\text { gemcitabine in two human } \\
\text { pancreatic cancer cell lines. }\end{array}$ & [91] \\
\hline \multicolumn{7}{|c|}{ Neurodegenerative diseases } \\
\hline VH14PEST & $\alpha$-synuclein & Parkinson's Disease & $\begin{array}{l}\text { PEST proteasome } \\
\text { targeting signal }\end{array}$ & $\begin{array}{l}\text { Transient transfection } \\
\text { in a differentiated } \\
\text { SH-SY5Y neuronal } \\
\text { cell line }\end{array}$ & $\begin{array}{l}\text { Intracellularly expressed VH14PEST } \\
\text { is able to significantly reduce aSyn } \\
\text { levels and protects cells against aSyn } \\
\text { toxicity. }\end{array}$ & [93-95] \\
\hline $\begin{array}{c}\text { VH14PEST, } \\
\text { NbSyn87PEST }\end{array}$ & $\alpha$-synuclein & Parkinson's Disease & $\begin{array}{l}\text { PEST proteasome } \\
\text { targeting signal }\end{array}$ & AAV-5 & $\begin{array}{l}\text { AAV-5 mediated in vivo delivery of } \\
\text { VH14PEST and NbSyn87PEST } \\
\text { resulted in a 2-fold reduction of } \\
\text { pathological aSyn aggregates. }\end{array}$ & [96] \\
\hline 3F5 & PABPN1 & $\begin{array}{l}\text { Oculopharyngeal } \\
\text { muscular dystrophy } \\
\text { (OPMD) }\end{array}$ & NLS-GFP fusion & Transient transfection & $\begin{array}{l}\text { 3F5 is not only able to prevent } \\
\text { PABPN1 aggregation, but also clears } \\
\text { existing aggregates upon } \\
\text { transfection in COS-1 cells }\end{array}$ & [108] \\
\hline 3F5, 3A9, 3E9 & PABPN1 & $\begin{array}{l}\text { Oculopharyngeal } \\
\text { muscular dystrophy } \\
\text { (OPMD) }\end{array}$ & NLS fusion & $\begin{array}{l}\text { In vivo expression in } \\
\text { Drosophila thoracic } \\
\text { muscle nuclei }\end{array}$ & $\begin{array}{l}\text { In vivo expression of } 3 \mathrm{~F} 5 \text { prevents } \\
\text { muscle degeneration, decreases } \\
\text { PABPN1 mutant aggregation and } \\
\text { restores muscle gene expression. }\end{array}$ & [109] \\
\hline
\end{tabular}


Table 1. Cont.

\begin{tabular}{|c|c|c|c|c|c|c|}
\hline VHH Identifier & Target & Indications & Modification & Delivery & Outcome & References \\
\hline \multicolumn{7}{|c|}{ Neurodegenerative diseases } \\
\hline VHHs 1-5 & Bax & $\begin{array}{l}\text { Alzheimer's disease, } \\
\text { Parkinson's Disease }\end{array}$ & / & $\begin{array}{l}\text { Stable mammalian } \\
\text { cell line }\end{array}$ & $\begin{array}{l}\text { Intracellular expression of Bax } \\
\text { VHHs blocks Bax function, resulting } \\
\text { in increased resistance to apoptosis } \\
\text { after oxidative stress. }\end{array}$ & [110] \\
\hline GSN Nb11 & Gelsolin & Gelsolin Amyloidosis & / & $\begin{array}{c}\text { Transgenic mice } \\
\text { expressing } \\
\text { ER-directed GSN } \\
\mathrm{Nb} 11 .\end{array}$ & $\begin{array}{l}\text { GSN Nb11 is able to shield gelsolin } \\
\text { from aberrant proteolysis. Nb11 } \\
\text { expressing gelsolin amyloidosis mice } \\
\text { display improved muscle } \\
\text { contraction. }\end{array}$ & [111] \\
\hline Nb11-FAF1 & Gelsolin & Gelsolin Amyloidosis & $\begin{array}{l}\text { Bispecific construct } \\
\text { separated by } \\
\text { MT1-MMP target } \\
\text { sequence }\end{array}$ & AAV-9 & $\begin{array}{l}\text { AAV-9 delivery of Nb11-FAF-1 in a } \\
\text { gelsolin amyloidosis mouse model } \\
\text { resulted in a significant drop in } \\
\text { aberrant gelsolin fragments in heart } \\
\text { and skeletal muscles. }\end{array}$ & [98] \\
\hline Nb190 & $\operatorname{Rev}$ & HIV-1 & / & Transient transfection & $\begin{array}{l}\mathrm{Nb} 190 \text { mimics the effects of } \\
\text { multimerization deficient Rev } \\
\text { mutants. Intracellular expression of } \\
\text { Nb190 resulted in a } 300 \text {-fold } \\
\text { reduction of HIV-1 replication. }\end{array}$ & [112] \\
\hline $\mathrm{Nb} 190$ & $\operatorname{Rev}$ & HIV-1 & l & $\begin{array}{c}\text { Stable VHH } \\
\text { expressing cell line }\end{array}$ & $\begin{array}{l}\text { Nb190 expressing cells display a } \\
\text { selective advantage upon infection } \\
\text { and are resistant to } 7 \text { HIV-1 subtypes. }\end{array}$ & [113] \\
\hline sdAb19 & Nef & HIV-1 & / & $\begin{array}{l}\text { Retroviral } \\
\text { transduction into fetal } \\
\text { liver cells followed by } \\
\text { transplantation in } \\
\text { irradiated host }\end{array}$ & $\begin{array}{l}\text { In vivo expression of sdAb19 in } \\
\text { thymocytes led to a significant } \\
\text { reduction of Nef induced CD4 } \\
\text { downregulation. }\end{array}$ & [114] \\
\hline BH-Int6 & Integrase & HIV-1 & GFP-fusion & Transient transfection & $\begin{array}{l}\text { A one-step bacterial two-hybrid } \\
\text { system allowed the isolation of of a } \\
\text { VHH with an affinity in the low } \\
\text { nanomolar range. }\end{array}$ & [115] \\
\hline
\end{tabular}


Table 1. Cont.

\begin{tabular}{|c|c|c|c|c|c|c|}
\hline VHH Identifier & Target & Indications & Modification & Delivery & Outcome & References \\
\hline \multicolumn{7}{|c|}{ Neurodegenerative diseases } \\
\hline $\begin{array}{l}\text { PEN-VHH6, } \\
\text { PEN-VHH24 }\end{array}$ & $\begin{array}{l}\text { Non-structural } \\
\text { protein 5B } \\
\text { (NS5B) }\end{array}$ & $\mathrm{HCV}$ & / & Penetratin $\mathrm{CPP}$ & $\begin{array}{l}\text { PEN-VHH6, PEN-VHH24 are able to } \\
\text { significantly reduce HCV replication } \\
\text { in vitro. }\end{array}$ & [116] \\
\hline $\begin{array}{c}\text { PEN-VHH7, } \\
\text { PEN-VHH9, } \\
\text { PEN-VH33, and PEN- } \\
\text { VH43 }\end{array}$ & $\begin{array}{l}\text { Non-structural } \\
\text { protein } 4 \mathrm{~B} \\
\text { (NS4B) }\end{array}$ & $\mathrm{HCV}$ & / & Penetratin $\mathrm{CPP}$ & $\begin{array}{l}\text { NS4B VHHs are able to significantly } \\
\text { reduce HCV replication in vitro. }\end{array}$ & [55] \\
\hline $\begin{array}{l}\text { VHH24, VHH28, } \\
\text { VHH41 }\end{array}$ & $\begin{array}{l}\text { Serine } \\
\text { protease }\end{array}$ & $\mathrm{HCV}$ & l & Penetratin CPP & $\begin{array}{l}\text { VHHs are able to significantly } \\
\text { reduce HCV replication in vitro. }\end{array}$ & [117] \\
\hline PEN-VHH9 & NS3 helicase & $\mathrm{HCV}$ & / & Penetratin CPP & $\begin{array}{l}\text { Addition of penatrin coupled } \mathrm{VHH} \\
\text { to the culture medium significantly } \\
\text { reduces subsequent } \mathrm{HCV} \text { infection } \\
\text { in vitro. }\end{array}$ & [118] \\
\hline VHH S2, S3, S4, S5 & $\begin{array}{l}\text { S protein } \\
\text { (HBsAg) }\end{array}$ & $\mathrm{HBV}$ & $\begin{array}{l}\text { Fusion to } \\
\text { ER-targeting signal } \\
\text { and SEKDEL ER } \\
\text { retention signal }\end{array}$ & $\begin{array}{l}\text { Injection of plasmid } \\
\text { DNA into mouse tail } \\
\text { vein }\end{array}$ & $\begin{array}{l}\text { VHH administration in a mouse } \\
\text { model led to an increase in cellularly } \\
\text { retained HBsAg and for some VHHs } \\
\text { an up to } 10 \text {-fold reduction of } \\
\text { secreted HBV virions. }\end{array}$ & [119] \\
\hline VHH C2, VHH C6 & $\begin{array}{l}\text { Core Antigen } \\
\text { (HBcAg) }\end{array}$ & HBV & l & Transient transfection & $\begin{array}{l}\text { HBcAg-specific VHHs targeted to } \\
\text { the nucleus abrogated intracellular } \\
\text { HBcAg signal. }\end{array}$ & [26] \\
\hline $\mathrm{Nb} 6$ & $\begin{array}{l}\text { Non-structural } \\
\text { protein } 9 \\
\text { (Nsp9) }\end{array}$ & PRRSV & I & $\begin{array}{l}\text { Stable VHH } \\
\text { expressing cell line }\end{array}$ & $\begin{array}{l}\text { Nb6 prevents the production of viral } \\
\text { RNA and fully blocked PRRSV } \\
\text { infection at MOI } 0.01 \text { in vitro. }\end{array}$ & [104] \\
\hline $\mathrm{Nb6}$ & $\begin{array}{l}\text { Non-structural } \\
\text { protein } 9 \\
\text { (Nsp9) }\end{array}$ & PRRSV & l & TAT CPP & $\begin{array}{l}\text { TAT-Nb6 was efficiently delivered } \\
\text { into porcine alveolar macrophages } \\
\text { and efficiently inhibited the } \\
\text { replication of several PRRSV strains. }\end{array}$ & [105] \\
\hline
\end{tabular}


Table 1. Cont.

\begin{tabular}{|c|c|c|c|c|c|c|}
\hline VHH Identifier & Target & Indications & Modification & Delivery & Outcome & References \\
\hline \multicolumn{7}{|c|}{ Neurodegenerative diseases } \\
\hline $\mathrm{Nb} 41, \mathrm{Nb} 43$ & $\begin{array}{l}\text { Non-structural } \\
\text { protein } 4 \\
\text { (Nsp4) }\end{array}$ & PRRSV & / & $\begin{array}{c}\text { Stable VHH } \\
\text { expressing cell line }\end{array}$ & $\begin{array}{l}\text { Intrabodies Nb41 and Nb43 } \\
\text { protected MARC-145 cells from } \\
\text { PRRSV induced cytopathic effect } \\
\text { and fully blocked viral replication at } \\
\text { an MOI of } 0.001 \text { or lower. }\end{array}$ & [103] \\
\hline $\mathrm{Nb9}$ & $\begin{array}{l}\text { Glycoprotein } 5 \\
\text { (GP5) } \\
\text { (Suspected) }\end{array}$ & PRRSV & l & $\begin{array}{l}\text { Lentiviral } \\
\text { transduction in } \\
\text { MARC-15 cells or } \\
\text { fusion to NLS-A CPP } \\
\text { from PCV2 Cap }\end{array}$ & $\begin{array}{l}\text { Lentiviral transduction of VHHs into } \\
\text { cells proves to be an efficient method } \\
\text { for the functional screening of } \\
\text { PRRSV inhibiting VHHs. }\end{array}$ & {$[72]$} \\
\hline $\mathrm{Nb} 1$ & $\begin{array}{l}\text { Non-structural } \\
\text { protein } 5 \\
\text { (NS5B) }\end{array}$ & BVDVR & / & $\begin{array}{c}\text { Stable VHH } \\
\text { expressing cell line }\end{array}$ & $\begin{array}{l}\mathrm{Nb} 1 \text { is able to significantly restrict } \\
\text { BVDVR replication at } 48 \mathrm{~h} \text { post } \\
\text { infection in vitro. }\end{array}$ & [107] \\
\hline JJX12 & $\begin{array}{l}\text { Ricin toxin } \\
\text { RTA and TRB } \\
\text { subunits }\end{array}$ & / & $\begin{array}{l}\text { Bispecific construct } \\
\text { linked by } 15-\text { mer } \\
\text { peptide }\end{array}$ & $\begin{array}{l}\text { Cellular uptake by } \\
\text { macropinocytosis }\end{array}$ & $\begin{array}{l}\text { The bispecific JJX12 binds ricin toxin } \\
\text { on the surface of cells followed by } \\
\text { co-internalization. JJX12 binding } \\
\text { inhibits retrograde transport of the } \\
\text { ricin to the TGN and traps the toxin } \\
\text { in the late endosomes. }\end{array}$ & {$[120,121]$} \\
\hline VHH5 & SpvB toxin & $\begin{array}{l}\text { Salmonella } \\
\text { typhimurium }\end{array}$ & / & Transient transfection & $\begin{array}{l}\text { When transfected into Vero cells or } \\
\text { RAW macrophages, VHH5 is able to } \\
\text { prevent SpvB induced actin } \\
\text { cytoskeleton disintegration. }\end{array}$ & [122] \\
\hline ALc-B8 & $\begin{array}{l}\text { Botulinum } \\
\text { neurotoxin } \\
(\text { BoNT) }\end{array}$ & Clostridium botulinum & YFP-fusion & Transient transfection & $\begin{array}{l}\text { Transfection of Alc-B8 efficiently } \\
\text { reduced BoNT induced SNAP } 25 \\
\text { cleavage compared to control } \\
\text { transfected cells. }\end{array}$ & [123] \\
\hline D5-B8 & $\begin{array}{l}\text { Botulinum } \\
\text { neurotoxin } \\
\text { (BoNT) }\end{array}$ & Clostridium botulinum & $\begin{array}{l}\text { Fusion to truncated } \\
\text { F-box domain }(\operatorname{TrCP})\end{array}$ & $\begin{array}{l}\text { Transient transfection } \\
\text { or lentiviral } \\
\text { transduction }\end{array}$ & $\begin{array}{l}\text { D5-B8 expressing neuronal cells } \\
\text { recovered 2,5 times faster from BoNT } \\
\text { intoxication than control cells. }\end{array}$ & [124] \\
\hline
\end{tabular}




\section{Use of Intrabodies as Research Tools}

Soon after the discovery of camelid heavy chain antibodies, the potential use of their variable domains as research tools was recognized. Their small size and tendency to bind cleft-like epitopes make them ideal molecules for targeting protein enzymatic sites and modulating their functionality. Moreover, due to the possibility to tag VHHs with all sorts of functional moieties, ranging from fluorophores to proteasomal degradation tags, the possibilities of intracellular VHHs as research tools are plentiful. Here, we provide an overview of recent studies in which intracellular VHHs were used to address research questions (Figure 3).
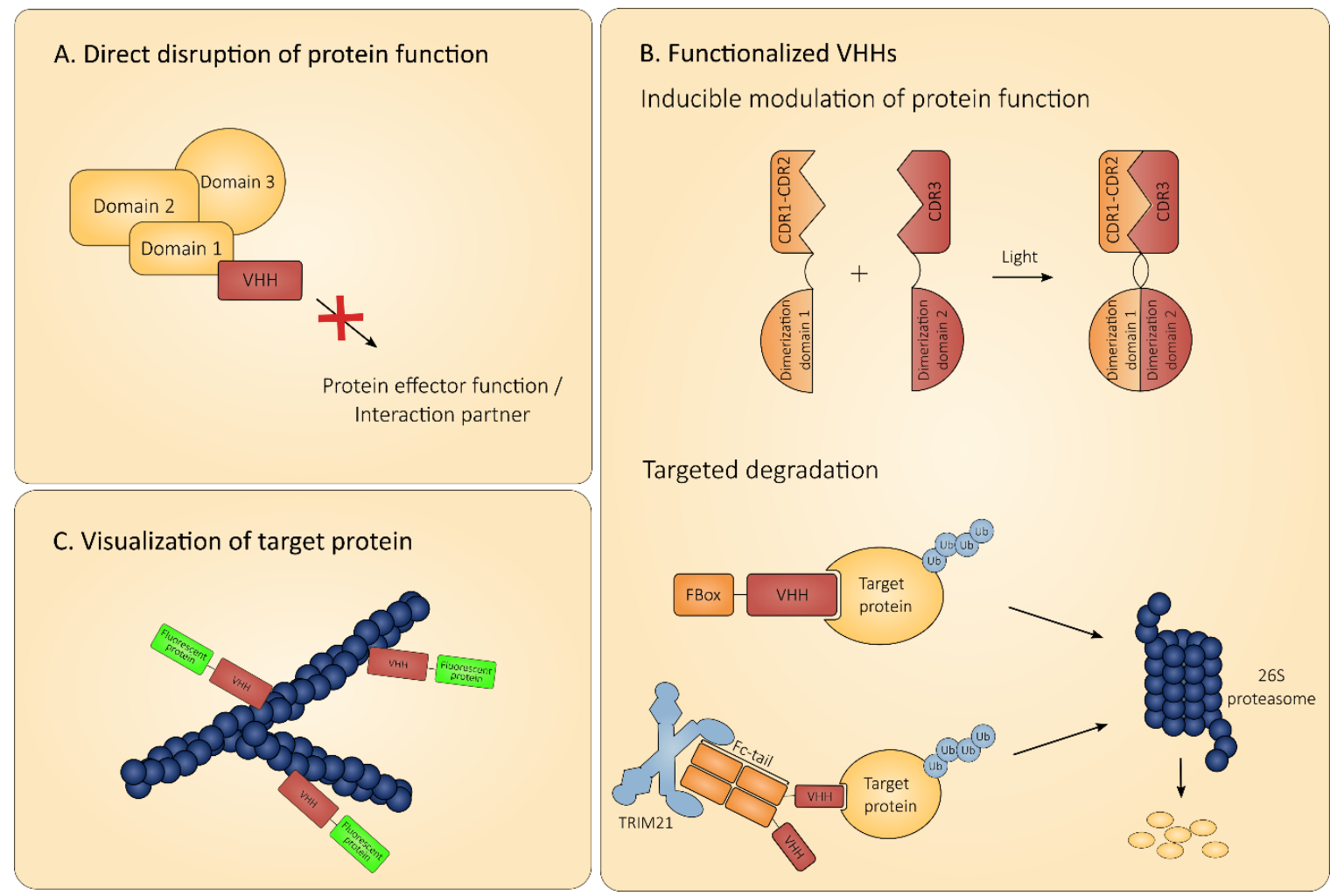

Figure 3. Schematic overview of the different uses of VHHs as research tools. (A) VHHs are able to target a particular protein domain, hereby inhibiting a specific protein effector function or a specific protein interaction. (B) VHHs can be coupled to functional groups. Creating a split VHH, coupled to light-sensitive dimerization domains, allows the precise timing of VHH modulation of target protein function [125]. On the other hand, coupling of VHHs to an F-box domain leads to the recruitment of cellular ubiquitin ligases, effectively marking the target protein for proteasomal degradation. Alternatively, coupling intracellular VHHs to and Fc-tail allows them to be recognized by tripartite motif-containing 21 (TRIM21), a cytosolic IgG receptor that can equally mark their target for proteasomal degradation, via its E3 ubiquitin ligase activity. (C) Chromobodies (CB) can be used to visualize and trace target proteins inside the cell.

\subsection{Intrabodies to Directly Probe Protein Functionality}

An important advantage that VHHs hold against classical protein knock-down strategies, such as $\mathrm{RNAi}$, is their ability to target specific protein domains, without disturbing the function of the entire protein. This can give rise to unprecedented insights in the functionality of the protein, as well as its interacting partners. In this way, it is possible to study the functionality of specific proteins and even protein domains with high precision in the context of larger protein complexes. One such example is the use of VHHs that bind distinct epitopes in the NTA domain of cortactin [126]. Cortactin is a multi-domain protein, that is involved in the activation of the Arp2/3 complex [127]. This complex 
is bound by the cortactin NTA domain, which leads to the formation of branched actin filaments. Meanwhile, the actin binding domains of cortactin are used to stabilize these newly formed actin branches. Actin polymerization and branching plays a role in the formation of invadopodia, which in turn are important for cancer cell extravasation and motility [128]. Two cortactin binding VHHs, $\mathrm{Nb} 2$ and $\mathrm{Nb} 3$, that bind the NTA domain of cortactin, were able to interfere with Arp2/3 mediated actin branching. It was demonstrated that, although both VHHs bind the same cortactin domain, $\mathrm{Nb} 3$ was able to disrupt the interaction with Arp2/3, while Nb2 was not. Additionally, it was shown that both VHHs could inhibit the formation of new actin branches in vitro, yet $\mathrm{Nb} 3$ expression also led to degradation of existing actin filaments. This translated to the distinct effect of the VHHs on invadopodium formation; while both VHHs interfere with the formation of new invadopodia, $\mathrm{Nb3}$ also seemed to have a destabilizing effect on existing invadopodia. This study demonstrates that with intracellular VHHs, it is possible to disrupt protein function with very high resolution, without resulting in a full knock-down. These findings not only bring insight into the complex process of actin filament formation and stabilization, but can also possibly have clinical value. As the authors suggest, delineating the epitopes of the VHHs, may aid in the development of new therapeutic inhibitors of cancer cell motility.

A second example of direct interference with protein function are VHHs that interact with the Shoc2 protein, a scaffold protein that regulates and finetunes signaling through the extracellular signal-regulated kinase (ERK) 1/2 pathway [129]. Two VHHs, named B99 and B120, were isolated from a synthetic humanized VHH library, and were found to be able to bind Shoc 2 with nanomolar affinity. Epitopes of the VHHs were located in a stretch of amino acids between the unstructured $\mathrm{N}$-terminus of Shoc2 and the C-terminal leucine rich repeat domain. Surprisingly, it was found that intracellular expression of the VHHs led to an increase in ERK1/2 phosphorylation, which resulted in increased pathway signaling. Moreover, when VHH B99 was co-expressed with a Shoc2-S2G mutant, which impairs signaling through the ERK1/2 pathway, it could partially restore ERK1/2 phosphorylation. These results indicate that the Shoc2 epitope that is targeted by VHH B99 and B120 might be involved in a negative feedback loop that modulates ERK1/2 signaling. Binding of the VHHs to this epitope would then render it inaccessible and may result in increased signaling through the ERK1/2 pathway. In humans, the S2G mutation in Shoc2 leads to the autosomal dominant Noonan syndrome with loose anagen hair [130]. Shoc2 VHHs that are able to counteract the detrimental effects of this mutation may thus not only be useful for elucidating the mechanism of Shoc2 function, but could also be explored for their therapeutic potential.

Another example in which VHHs can very precisely interfere with protein function comes from a study published by Tome-Amat et al. [131]. Here, a previously isolated VHH targeting the nucleoprotein of IAV (NP) was used to characterize the function of NP in the import of viral ribonucleoprotein complexes (vRNPs) into the nucleus. Ashour et al. had previously demonstrated that this NP-VHH was able to interfere with IAV infection and that this restriction occurred at a step prior to nuclear import of the viral genomes [132]. It was further shown by Tome-Amat et al. that this VHH interfered with the ability of NP to bind $\alpha$-importins, which is necessary for efficient nuclear import of the vRNPs. Interactions between NP and $\alpha$-importins are transient and have a low affinity. The authors reasoned that in order to obtain efficient import, avidity of the interaction is likely to be important and set out to determine how many of these interactions were necessary to support nuclear vRNP import. An NP-specific VHH coupled to the NLS of the NP was used to 'outsource' the interaction with $\alpha$-importins from NP to the VHH. In this way, by varying the ratio of NP-VHH and NP-VHH-NLS delivered to the cells, the number of accessible NLS sequences for interaction with $\alpha$-importins, could be determined. From this experiment, it was estimated that about $20 \%$ of NLS sequences should be available for interaction in order to obtain efficient nuclear import. This number however varied in different cell types, and the amount of free NLS needed correlated with the infectivity of the cell line. The authors also investigated what would happen if vRNPs are retained in the cytoplasm by preventing their interaction with $\alpha$-importins. It was shown that retention of vRNPs rapidly results in an upregulation 
of type I interferons, hereby confirming the hypothesis that IAV replication in the nucleus allows the virus to avoid cytosolic innate immune sensors. NP is a notoriously difficult target to manipulate, due to its central role in IAV infection and replication. Knock-down and genetic engineering often result in replication deficient viruses. Intracellular VHHs on the other hand, allow very precise manipulation of NP function in the limited timeframe between membrane fusion and nuclear import, again proving their value as basic research tools.

Studying protein function using VHHs offers the possibility to specifically target certain protein domains, rather than disrupting full protein function. This approach is especially useful for proteins that are difficult to manipulate, due to their essential function, or proteins that serve as scaffolds for numerous other interaction partners. The above studies nicely illustrate how the highly specific binding of VHHs can be used to pinpoint protein sites with high resolution, and how the resulting functional analysis may not only lead to new insights in protein functionality, but also shine a light on possible new therapeutic targets.

\subsection{Functionalized Intrabodies}

VHHs can be coupled to a wide range of functional groups, which allows them to modulate their targets functionality. Recent advances in the field demonstrate how functionalized VHHs can reversibly switch off the signaling activity of cellular receptors, or very precisely target certain protein conformations for proteasomal degradation. These studies highlight once more the unsurpassed precision and flexibility of using intracellular VHHs as research tools.

\subsubsection{Modulating Protein Function}

G protein coupled receptors (GPCRs) play numerous roles in many cellular pathways. To better understand the physiological function of GPCRs, it is of interest to be able to target only a specific subset of these receptors, of which over 800 family members have been identified in the human genome [133]. In a recent study, Farrants et al. applied a novel method to reversibly switch off signaling by the G protein-coupled metabotropic glutamate receptors (mGluRs) [134]. For this purpose, the mGluR was coupled to GFP, and targeted using a well described GFP-specific VHH. This VHH was genetically fused to a SNAP-tag, a $19.4 \mathrm{kDa}$ polypeptide which can readily interact with several functional groups, such as different fluorophores, dyes or photoswitches. By subsequently adding a photo switchable molecule, which interacts with the VHH-SNAP fusion, reversible activation and inactivation of the mGluR signaling was obtained, by simply switching off or on $380 \mathrm{~nm}$ illumination, respectively. Activity of the mGluR was monitored indirectly, by measuring the ion flow through co-transfected $\mathrm{G}$ protein-gated inward rectifying potassium channels, a well-defined downstream effector of mGluR, by patch clamp electrophysiology. This elegant method using VHH-photoswitch conjugates allows very precise and reversible optical control of the target protein and can easily be expanded for the study of other endogenous cellular receptors.

Another example of the use of intrabodies for the precise spacio-temporal control of target proteins was recently described by Yu et al. [125]. In this study, split intrabody fragments are coupled to blue light-inducible heterodimerization domains, creating so-called optobodies. Using a GFP binding VHH for proof of concept, it was demonstrated that in order to retain antigen binding after dimerization, the intrabody could best be split so that one part contains CDR1 and 2 and the second part holds CDR3. Next, the VHH segments were coupled to blue light-inducible dimerization domains, and it was demonstrated that dimerization could be induced with high spacio-temporal precision. The affinity of the reconstituted GFP VHH appeared to be equal to that of the original VHH. Furthermore, the GFP optobody remained intact as long as its target was present, indicating that optobody activation is irreversible due to the high affinity for its target. The authors further expanded their toolbox by developing optobodies against gelsolin and the $\beta 2$ adrenergic receptor ( $\beta 2 \mathrm{AR})$. Upon light activation, the mito-conjugated gelsolin-specific optobody was able to translocate its target to the mitochondria, while the $\beta 2 \mathrm{AR}$-specific optobody accumulated at the plasma membrane, where its target resides. 
Expression of the anti-gelsolin optobody in NIH3T3 cells resulted in a significant decrease in cell motility when treated with blue light, but not in the dark, as demonstrated by tracking individual cells using live cell imaging. Moreover, the motility of single cells could be manipulated by targeted blue light induction, underlining the high spatial precision of the optobody technique. Similarly, the $\beta 2 \mathrm{AR}$ optobody was able to inhibit $\beta 2 \mathrm{AR}$ signaling in HEK239T cells, by inhibition of receptor internalization. The optobody technique provides a platform for the light-inducible activation of intracellular VHHs and could be used for the manipulation of numerous endogenous targets. One case in which optobodies may also prove to be of added value is in the context of elucidating the mechanism of an antiviral protein. For example, light-inducible activation of an antiviral protein using an optobody at different time points post infection, may help to pinpoint the exact phase of the infection cycle that is targeted by this protein.

VHHs have also been used for the targeted degradation of specific protein conformational states [135]. RHOB belongs to the Ras-related family of the RHO GTPases and exists as pools of GDP-bound and GTP-bound forms in the cytoplasm [136]. RHOB distinguishes itself from other RHO GTPases by its unique C-terminus, which is prone to modifications with several post-translational modifications, which each confer a specific localization and function to RHOB. Because of this, a role for RHOB has been implied in several cellular processes, among which regulation of the DNA damage response and intracellular trafficking [137]. Despite the involvement of RHOB in many cellular processes, its molecular mechanism remains unclear. To address this, Bery et al. generated a method to selectively target GTP-bound form of RHOB for degradation, by making use of RHOB-GTP specific VHHs, which were selected from a synthetic humanized VHH library. VHHs that were able to target intracellular RHOB were selected using an elegant functional screening strategy. Enriched VHHs were cloned into a bicistronic vector that allowed the VHH to be expressed as an F-box-VHH coupled to a GFP protein with a mitochondrial targeting sequence (MitoGFP). The F-box conjugated VHH results in degradation of its target, while the MitoGFP allows for rapid detection of cells that express a functional intrabody. Transfection of these bicistronic constructs in cells that express an RFP labeled RHOB, resulted in easy detection of cells expressing a functional F-box-VHH, by selection of cells with a decreased RFP signal and green mitochondria. This selection strategy resulted in the identification of one VHH that was able to induce selective degradation of endogenous RHOB-GTP levels when expressed intracellularly. The specificity of this VHH for the GTP-bound state of RHOB, versus the GDP-bound state, was demonstrated by co-immunoprecipitation experiments. Degradation of RHOB-GTP led to significantly higher levels of DNA damage markers and a marked increase in cell migration, indicating that RHOB-GTP, but not RHOB-GDP, is responsible for maintaining genome stability and suppression of cell invasiveness. This selection method can be expanded to identify F-box-VHHs against several other family members of the small GTPases and aid in elucidating their functions.

Another recent technique for the rapid and specific degradation of endogenous proteins is based on the finding that antibody bound pathogens can be recognized by the cytosolic IgG-receptor tripartite motif-containing 21 (TRIM21) [138]. TRIM21 is a cytosolic E3 ubiquitin ligase that binds Fc-domains with very high affinity (around $0.6 \mathrm{nM}$ ) and rapidly recruits the proteasomal degradation machinery upon binding [138]. Inspired by these findings, Clift et al. developed a technique for the knock-down of endogenous proteins by labeling them for TRIM21-mediated degradation, an approach that they named Trim-Away [139]. The Trim-Away method is based on the delivery of recombinant TRIM21 and target-specific antibodies into cells. As a proof of concept, NIH3T3 cells that overexpress mCherry-TRIM21 and GFP were micro-injected with anti GFP antibody. This led to the rapid degradation of GFP, with a half-life of only $16 \mathrm{~min}$, and was paired with a clear colocalization of the mCherry labeled TRIM21 and GFP. However, this experimental set-up was not successful for the degradation of exclusively nuclear, chromatin-associated H2B-GFP. The authors reasoned that this was likely due to the size of the antibody molecules and reasoned that much smaller VHH-FC fusions may be able to cross the nuclear envelope. Indeed, administration of a GFP-VHH Fc-fusion construct to cells expressing H2B-GFP led to a rapid decrease of the nuclear GFP signal. The authors 
further demonstrated the use of Trim-Away in non-dividing primary cells, for which genome- and RNA targeting have proven to be challenging. Interestingly, the technique is also effective when only endogenous TRIM21 is present, foregoing the need of genetic engineering of the target cells or the addition of recombinant TRIM21 [139]. Combining Trim-Away with Fc-coupled VHHs may prove to be another promising technique for the rapid and precise degradation of endogenous proteins.

The above studies demonstrate how the coupling of intrabodies to functional moieties provides a plethora of possibilities to study protein functions. Other examples include using intrabodies as a tool for protein relocalization, resulting in a functional knock out [140-143], or allowing the study of protein-protein interactions [56]. More recently, Prole and Taylor have generated a toolbox of functionalized VHH intrabodies that target common fluorescent protein tags [144]. VHHs that target GFP and RFP, as well as some of their variants, were fused to many different functional modules, including fluorescent sensors for $\mathrm{Ca}^{2+}$ and $\mathrm{H}^{+}$, oligomerizing modules and SNAP-tags. This opens up many possibilities for the study of the wide range of fluorophore labeled proteins that are currently available.

\subsubsection{Visualization of Protein Targets}

The use of fluorescent protein-conjugated VHHs, or chromobodies (CBs), is a well know application of VHH technology. The term chromobodies was first coined by Rothbauer et al., when they described a GFP binding RFP-fused VHH [66]. Chromobodies usually do not interfere with protein functionality and are able to track endogenous proteins in living cells, something that was previously impossible using classical antibodies. Moreover, the use of chromobodies abrogates the need for fluorescently labeled target proteins, which may differ significantly from their endogenous counterparts in terms of expression level, localization, stability and functionality. In this part, an overview of recent studies using chromobodies for protein visualization is given.

Chromobodies have been commonly used for the visualization and study of cytoskeleton structures. One such a component of the cytoskeleton, vimentin, has been shown to be involved in the switch to an invasive cellular phenotype in various epithelial cancer types and is thus associated with poor prognosis for cancer progression $[145,146]$. Intracellular expression of vimentin CBs was used to visualize the real-time dynamic changes of vimentin in A549 cells [147]. Application of this CB in vivo could aid in the further elucidation of vimentin-driven EMT processes [148]. Actin is another component of the cytoskeleton that has been extensively studied using CBs. In a recent study, Wegner et al. have used an actin $\mathrm{CB}$ for the in vivo visualization of neuronal actin filaments using super-resolution microscopy [149]. Furthermore, CBs have been extensively used for the study of actin filaments in several parasitic organisms, such as Toxoplasma gondii and Plasmodium falciparum [150-152].

Chromobodies have also been used as a tool to study RHO small GTPase activation [153]. RHO GTPases play a crucial role in the assembly of actin filaments, resulting in the formation of lamellipodia, filopodia and other actin-based structures necessary for cell migration [154]. A VHH that recognizes, but does not interfere with the activity of the active, GTP-bound forms of RHOA, RHOB and RHOC, was isolated from a synthetic library. This VHH was subsequently modified to function as a biosensor for RHO small GTPase activation, using Bioluminescence Resonance Energy Transfer (BRET). For this purpose, the VHH was N-terminally fused to a $\mathrm{GFP}^{2}$ acceptor molecule and co-expressed with a RenillaLuc-RHO fusion construct. Administration of the renilla luciferase substrate, coelenterazine 400a, led to a significant increase of the BRET signal in the presence of RHOA, RHOB and RHOC, indicating that the intracellular VHH can specifically interact with these three $\mathrm{RHO}$ isoforms. The authors further suggested that this biosensor could be used in the future for the screening of small molecule modulators of RHOA/B/C activity.

Keller et al. reported that rising of antigen levels led to a dramatic increase of the signal of stably expressed CBs [155]. This effect appeared to be common to many different CBs and was named antigen mediated CB stabilization (AMCBS). The varying CB signals corresponding to respective antigen levels, appeared to be quantitative and allowed simultaneous visualization and quantification of changing 
endogenous antigen concentrations. The authors set out to improve the dynamic range of this assay by screening for mutations of the $\mathrm{N}$-terminal amino acid residue that destabilize the $\mathrm{CB}$, thus increasing its turnover rate. This phenomenon is known as the $\mathrm{N}$-end rule, which states that certain $\mathrm{N}$-terminal amino acids dramatically decrease protein half-life, due to stronger interaction with E3 ubiquitin ligases $[156,157]$. The screening for destabilizing N-terminal amino acids was done using the ubiquitin fusion technique, which encompasses the co-translational cleavage of an $\mathrm{N}$-terminal ubiquitin fusion construct [158]. In this way, a set of identical CBs could be expressed, which only differed at the site of their N-terminal amino acid. It appeared that both Phe and Arg as N-terminal amino acids resulted in a rapid degradation of the $C B$. These turn-over accelerated CBs were able to accurately reflect the variable levels of endogenous non-membrane associated $\beta$-catenin upon addition of specific antigen inhibitors, making it even possible to distinguish between the different kinetics of both inhibitors. With a growing number of chromobodies being engineered, the authors suggest that the time-resolved quantification of many other proteins will be possible in the near future.

Chromobodies are an excellent tool for the study of endogenous proteins in a live cell imaging context. The use of stable cell lines expressing these CBs allows straightforward tracking of proteins of interest. However, there are several downsides to the stable genomic integration of CBs, for example the increased chance of aggregation or misfolding upon expression driven by very strong promoters. Furthermore, random insertion always poses the risk of disturbing essential cellular processes. As a solution to these problems, Keller et al. have proposed a strategy to optimize the generation of stable CB cell lines [159]. Firstly, expression of the CB as N-terminal ubiquitin fusion proteins improves solubility, while also allowing insertion of an N-terminal amino acid of choice in the chromobody sequence [158]. As described above, expression of CBs with an N-terminal Arg residue results in a higher $\mathrm{CB}$ turnover and increased antigen sensitivity [155]. The authors also suggest the use of the elongation factor $1 \alpha(\mathrm{EF} 1 \alpha)$ promoter to drive $\mathrm{CB}$ expression, as it is less sensitive to epigenetic silencing than the commonly used CMV-promoter [160]. As a last optimization step, the CB sequence is delivered into the cells by site directed integration using the CRISPR/Cas9 technology. For this, the authors chose the adenovirus-associated virus site 1 , which has been reported to be a safe harbor for genomic integration $[161,162]$. This approach allows the generation of stable CB producing cell lines suitable for prolonged culturing.

While fusions of VHHs to fluorescent proteins are useful for creating stable cell lines, they offer little flexibility regarding the choice of fluorophore and the addition of a bulky fluorescent protein increases the distance of the fluorophore to the target, decreasing resolution. As a solution to this problem, VHHs can also be directly coupled to fluorophores using click-chemistry. For this purpose, the $\mathrm{VHH}$ sequences can be engineered to contain either an extra cysteine residue [163] or an unnatural amino acid [164]. Such VHHs, directly labeled with Alexa fluor 647, have been successfully used for high-resolution imaging of nuclear pore complexes [163]. In another example, directly labeled VHHs were delivered into living cells by photoporation and used for imaging of cortactin structures [164]. This last approach also allows the visualization of short-term target perturbation, which would not be feasible using genetically encoded chromobodies.

\section{Concluding Remarks}

Many recent studies that focus on protein functionality have underlined the utility of intracellular VHHs as research tools. Intracellular VHHs can modulate their target in a myriad of ways, such as direct disruption of protein function or locking their target in a particular conformational state. Furthermore, intracellular VHHs can also be coupled to a wide range of functional groups, which allows them to be used for localization studies, sensors for enzyme activity and as proteasomal degradation tags. These studies have led to novel insights that, in the longer run, may contribute to the discovery of new therapeutic possibilities.

Therapeutic VHHs can be expressed inside cells in different ways. VHH gene delivery using viral vectors may be particularly interesting in cases of diseases caused by protein defects, such as tauopathies 
and other protein misfolding disorders. Other maladies, such as cancer, require the therapeutic to be delivered at the site of the lesion. Here, VHHs with intracellular targets face the problem of crossing the cell membrane, although solutions to this problem, such as fusing the VHHs to cell penetrating peptides or reshaping their surface to facilitate membrane crossing, have been demonstrated to work in vitro. Another challenge these potentially therapeutic VHHs face is efficient targeting to their site of action, while avoiding rapid clearance from circulation. A benefit of intracellular VHHs in this case, is that once therapeutic intrabodies reach their site of action and enter the cell, they are protected from renal clearance [58]. Due to their formatting flexibility, VHHs can easily be coupled to specific targeting groups, be it other VHHs or even mAbs. For example, VHHs have recently been demonstrated to be promising targeting groups for chimeric antigen receptor $\mathrm{T}$ cells [165]. On the other hand, coupling to the CD4-targeting mAb ibalizumab was shown to efficiently concentrate HIV-1 broadly neutralizing VHHs at the site of infection [166].

Ever since their discovery, the use of VHHs as both research tools and biopharmaceuticals has been extensively explored. The realization that VHHs retain their binding capacities in the cytoplasm of cells opened up a whole new range of proteins that could now be targeted. The use of screening methods designed for intrabody discovery and standardized frameworks that allow intracellular expression will accelerate the selection of functional intracellular VHHs and hopefully lead to many more exciting discoveries.

\section{Boxes}

\subsection{BOX 1: Single Domain Antibody Libraries}

The default procedure to obtain high affinity VHHs makes use of immune libraries. For this strategy a camelid is immunized several times with purified recombinant protein, in the presence of an adjuvant, which typically results in a very robust immune response consisting of both classical and heavy chain antibodies. After immunization, a blood sample is collected from which the peripheral blood lymphocytes are isolated. These are then used for RNA isolation followed by selective amplification of the VHH sequences by RT-PCR. The VHH sequences can then be cloned into the desired display vector [167]. Immune libraries are often the preferred source of highly specific VHHs obtained through the process of in vivo affinity maturation. In some cases, the large amount (approximately $1 \mathrm{mg}$ ) of purified protein needed for the immunization can pose a problem. Alternative immunization strategies however, such as DNA immunization $[168,169]$, immunization with cells expressing the antigen [170] or immunization with inactivated viruses [71] have been proven to be successful. In cases where animal immunization is not possible, due to toxicity or lack of immunogenicity of the antigen, naïve or synthetic libraries can be used. As there is no affinity maturation in these cases, library sizes must be of a significant size ( $10^{9}$ individual clones) and complexity in order to obtain high affinity VHH candidates [171]. Nonetheless, naïve camelid VHH libraries have been successfully used for the isolation of high affinity binders $[172,173]$. The first fully synthetic phage display library of humanized llama single domain antibodies (NaLi-H1) was created by Moutel et al. [174]. Starting from a highly stable VHH consensus scaffold, which was optimized for intracellular expression, synthetic variability was introduced into the CDRs based on a set of naturally occurring amino acids in these sequences. The resulting VHH library consists of $3 \times 10^{9}$ individual clones and was successfully used for the retrieval of high affinity VHHs targeting a diverse set of antigens [174]. It is important to note that some of these synthetic libraries are IP protected. Currently, some companies, such as Creative Biolabs and Hyrbigenics, offer services for design and/or screening of synthetic libraries.

\subsection{BOX 2: Single Domain Antibody Selection Methods}

The most often used method for selection of specific binders from VHH libraries is phage display $[167,171]$. For this technology, the amplified VHH coding sequences are cloned into a phagemid vector and transformed into E. coli. Infection of the bacterial cells with helper phages results in the 
secretion of filamentous phages that each have a VHH fused to one of their coat proteins, thus effectively combining both the VHH coding sequence and translated protein into a single organism. Phages are subsequently precipitated from the supernatant using polyethylene glycol and transferred to a micro well containing the immobilized antigen. After stringent washing to remove unbound or weakly bound phages, strong binders are eluted and used to re-infect bacterial cells. Superinfection with helper phages will again result in the production of new VHH carrying phages which have now been enriched for the target antigen. This process, called bio panning, is repeated for several rounds to obtain high affinity VHHs. VHHs can also be expressed on the surface of bacterial or yeast cells [175-177]. The main advantage of yeast display is the ability to screen for $\mathrm{VHH}$ target binding using fluorescence assisted cell sorting (FACS). Using a two-color staining procedure, VHHs can easily be selected based on both $\mathrm{VHH}$ expression level and affinity. Another selection method for enrichment of VHHs is ribosome display, whereby the $\mathrm{VHH}$ sequence is fused to an arrest sequence, which prevents the protein from being released from the ribosome during translation. This method effectively couples the VHH mRNA sequence to the newly synthesized protein, via the ribosome. These mRNA-VHH-ribosome complexes are then also used for panning on immobilized antigen. Ribosome display can be performed both in vitro and in vivo. Bencurova et al. designed a universal cassette for the synthesis of mRNA-VHH-ribosome complexes in different expression systems [178]. Addition of a myc-tag and mCherry reporter sequence allows for easy purification of ribosome complexes as well as rapid assessment of translation efficiency. For the specific enrichment of intracellular nanobodies, the use of a bacterial-two-hybrid system has been suggested [115]. Here, the antigen and the VHH library are each fused to one part of split dihydrofolate reductase. Only in case of $\mathrm{VHH}$ binding will the enzyme be reconstituted and can cells survive in the presence of the toxic compound trimethoprim. However, in order to obtain high affinity binding VHHs with this technique it is essential that an immune library is used as a starting point, as the in vivo affinity maturation process allows to screen a smaller number of clones.

Author Contributions: E.S., conceptualization, review of the literature and original draft preparation; M.B. and X.S. conceptualization and supervision. All the authors contributed to the final draft and revised the manuscript. All authors have read and agreed to the published version of the manuscript.

Funding: E.S. was supported by an FWO research grant (\#G0B1917N).

Conflicts of Interest: The authors declare no conflict of interest.

\section{References}

1. Hamers-Casterman, C.; Atarhouch, T.; Muyldermans, S.; Robinson, G.; Hammers, C.; Songa, E.B.; Bendahman, N.; Hammers, R. Naturally Occurring Antibodies Devoid of Light Chains. Nature 1993, 363, 446-448. [CrossRef] [PubMed]

2. Blanc, M.R.; Anouassi, A.; Abed, M.A.; Tsikis, G.; Canepa, S.; Labas, V.; Belghazi, M.; Bruneau, G. A One-Step Exclusion-Binding Procedure for the Purification of Functional Heavy-Chain and Mammalian-Type $\gamma$-Globulins from Camelid Sera. Biotechnol. Appl. Biochem. 2009, 54, 207-212. [CrossRef] [PubMed]

3. Greenberg, A.; Avila, D.; Hughes, M.; Hughes, A.; McKinney, C.E.; Flajnik, M.F. A New Antigen Receptor Gene Family That Undergoes Rearrangement and Extansive Somatic Diversification in Sharks. Nature 1995, 374, 168-173. [CrossRef] [PubMed]

4. Streltsov, V.A.; Carmichael, J.A.; Nuttall, S.D. Structure of a Shark IgNAR Antibody Variable Domain and Modeling of an Early-Developmental Isotype. Protein Sci. 2005, 14, 2901-2909. [CrossRef]

5. Stanfield, R.L.; Dooley, H.; Flajnik, M.F.; Wilson, I.A. Crystal Structure of a Shark Single-Domain Antibody V Region in Complex with Lysozyme. Science (80-) 2004, 305, 1770-1773. [CrossRef]

6. Van Der Linden, R.H.J.; Frenken, L.G.J.; De Geus, B.; Harmsen, M.M.; Ruuls, R.C.; Stok, W.; De Ron, L.; Wilson, S.; Davis, P.; Verrips, C.T. Comparison of Physical Chemical Properties of Llama V(HH) Antibody Fragments and Mouse Monoclonal Antibodies. Biochim. Biophys. Acta Protein Struct. Mol. Enzymol. 1999, 1431, 37-46. [CrossRef]

7. De Genst, E.; Saerens, D.; Muyldermans, S.; Conrath, K. Antibody Repertoire Development in Camelids. Dev. Comp. Immunol. 2006, 30, 187-198. [CrossRef] 
8. Muyldermans, S.; Atarhouch, T.; Saldanha, J.; Barbosa, J.A.R.G.; Hamers, R. Sequence and Structure of vh Domain from Naturally Occurring Camel Heavy Chain Immunoglobulins Lacking Light Chains. Protein Eng. Des. Sel. 1994, 7, 1129-1135. [CrossRef]

9. Vu, K.B.; Ghahroudi, M.A.; Wyns, L.; Muyldermans, S. Comparison of Llama V(H) Sequences from Conventional and Heavy Chain Antibodies. Mol. Immunol. 1997, 34, 1121-1131. [CrossRef]

10. Harmsen, M.M.; Ruuls, R.C.; Nijman, I.J.; Niewold, T.A.; Frenken, L.G.J.; De Geus, B. Llama Heavy-Chain V Regions Consist of at Least Four Distinct Subfamilies Revealing Novel Sequence Features. Mol. Immunol. 2000, 37, 579-590. [CrossRef]

11. Maass, D.R.; Sepulveda, J.; Pernthaner, A.; Shoemaker, C.B. Alpaca (Lama Pacos) as a Convenient Source of Recombinant Camelid Heavy Chain Antibodies (VHHs). J. Immunol. Methods 2007, 324, 13-25. [CrossRef] [PubMed]

12. Davies, J.; Riechmann, L. “Camelising” Human Antibody Fragments: NMR Studies on VH Domains. FEBS Lett. 1994, 339, 285-290. [CrossRef]

13. De Genst, E.; Silence, K.; Decanniere, K.; Conrath, K.; Loris, R.; Kinne, J.; Muyldermans, S.; Wyns, L. Molecular Basis for the Preferential Cleft Recognition by Dromedary Heavy-Chain Antibodies. Proc. Natl. Acad. Sci. USA 2006, 103, 4586-4591. [CrossRef] [PubMed]

14. Govaert, J.; Pellis, M.; Deschacht, N.; Vincke, C.; Conrath, K.; Muyldermans, S.; Saerens, D. Dual Beneficial Effect of Interloop Disulfide Bond for Single Domain Antibody Fragments. J. Biol. Chem. 2012, 287, 1970-1979. [CrossRef] [PubMed]

15. Ahmad, Z.A.; Yeap, S.K.; Ali, A.M.; Ho, W.Y.; Alitheen, N.B.M.; Hamid, M. ScFv Antibody: Principles and Clinical Application. Clin. Dev. Immunol. 2012, 2012. [CrossRef] [PubMed]

16. Yau, K.Y.F.; Dubuc, G.; Li, S.; Hirama, T.; MacKenzie, C.R.; Jermutus, L.; Hall, J.C.; Tanha, J. Affinity Maturation of a VHH by Mutational Hotspot Randomization. J. Immunol. Methods 2005, 297, $213-224$. [CrossRef]

17. Koide, A.; Tereshko, V.; Uysal, S.; Margalef, K.; Kossiakoff, A.A.; Koide, S. Exploring the Capacity of Minimalist Protein Interfaces: Interface Energetics and Affinity Maturation to Picomolar KD of a Single-Domain Antibody with a Flat Paratope. J. Mol. Biol. 2007, 373, 941-953. [CrossRef]

18. Dumoulin, M.; Conrath, K.; Van Meirhaeghe, A.; Meersman, F.; Heremans, K.; Frenken, L.G.J.; Muyldermans, S.; Wyns, L.; Matagne, A. Single-Domain Antibody Fragments with High Conformational Stability. Protein Sci. 2002, 11, 500-515. [CrossRef]

19. Chen, S.; Bagley, J.; Marasco, W.A. Intracellular Antibodies as a New Class of Therapeutic Molecules for Gene Therapy. Hum. Gene Ther. 1994, 5, 595-601. [CrossRef]

20. Biocca, S.; Ruberti, F.; Tafani, M.; Pierandrei-Amaldi, P.; Cattaneo, A. Redox State of Single Chain Fv Fragments Targeted to the Endoplasmic Reticulum, Cytosol and Mitochondria. Nat. Biotechnol. 1995, 13, 1110-1115. [CrossRef]

21. Shaki-Loewenstein, S.; Zfania, R.; Hyland, S.; Wels, W.S.; Benhar, I. A Universal Strategy for Stable Intracellular Antibodies. J. Immunol. Methods 2005, 303, 19-39. [CrossRef] [PubMed]

22. Proba, K.; Wörn, A.; Honegger, A.; Plückthun, A. Antibody ScFv Fragments without Disulfide Bonds Made by Molecular Evolution. J. Mol. Biol. 1998, 275, 245-253. [CrossRef] [PubMed]

23. Philibert, P.; Stoessel, A.; Wang, W.; Sibler, A.P.; Bec, N.; Larroque, C.; Saven, J.G.; Courtête, J.; Weiss, E.; Martineau, P. A Focused Antibody Library for Selecting ScFvs Expressed at High Levels in the Cytoplasm. BMC Biotechnol. 2007, 7, 1-17. [CrossRef]

24. Li, T.; Bourgeois, J.P.; Celli, S.; Glacial, F.; Le Sourd, A.M.; Mecheri, S.; Weksler, B.; Romero, I.; Couraud, P.O.; Rougeon, F.; et al. Cell-Penetrating Anti-GFAP VHH and Corresponding Fluorescent Fusion Protein VHH-GFP Spontaneously Cross the Blood-Brain Barrier and Specifically Recognize Astrocytes: Application to Brain Imaging. FASEB J. 2012, 26, 3969-3979. [CrossRef] [PubMed]

25. Kunz, P.; Zinner, K.; Mücke, N.; Bartoschik, T.; Muyldermans, S.; Hoheisel, J.D. The Structural Basis of Nanobody Unfolding Reversibility and Thermoresistance. Sci. Rep. 2018, 8, 1-10. [CrossRef]

26. Serruys, B.; Van Houtte, F.; Farhoudi-Moghadam, A.; Leroux-Roels, G.; Vanlandschoot, P. Production, Characterization and in Vitro Testing of HBcAg-Specific VHH Intrabodies. J. Gen. Virol. 2010, 91, 643-652. [CrossRef]

27. Marschall, A.L.J.; Dübel, S.; Böldicke, T. Specific in Vivo Knockdown of Protein Function by Intrabodies. MAbs 2015, 7, 1010-1035. [CrossRef] 
28. Alirahimi, E.; Ashkiyan, A.; Kazemi-Lomedasht, F.; Azadmanesh, K.; Hosseininejad-Chafi, M.; Habibi-Anbouhi, M.; Moazami, R.; Behdani, M. Intrabody Targeting Vascular Endothelial Growth Factor Receptor-2 Mediates Downregulation of Surface Localization. Cancer Gene Ther. 2017, 24, 33-37. [CrossRef]

29. Lin, J.J.C.; Feramisco, J.R. Disruption of the in Vivo Distribution of the Intermediate Filaments in Fibroblasts through the Microinjection of a Specific Monoclonal Antibody. Cell 1981, 24, 185-193. [CrossRef]

30. Benavente, R.; Krohne, G. Involvement of Nuclear Lamins in Postmitotic Reorganization of Chromatin as Demonstrated by Microinjection of Lamin Antibodies. J. Cell Biol. 1986, 103, 1847-1854. [CrossRef]

31. Kaczmarek, L.; Miller, M.R.; Hammond, R.A.; Mercer, W.E. A Microinjected Monoclonal Antibody against Human DNA Polymerase- $\alpha$ Inhibits DNA Replication in Human, Hamster, and Mouse Cell Lines. J. Biol. Chem. 1986, 261, 10802-10807. [PubMed]

32. Arnheiter, H.; Haller, O. Antiviral State against Influenza Virus Neutralized by Microinjection of Antibodies to Interferon-Induced Mx Proteins. EMBO J. 1988, 7, 1315-1320. [CrossRef] [PubMed]

33. Morgan, W.F.; Day, J.P. The Introduction of Proteins into Mammalian Cells by Electroporation. Methods Mol. Biol. 1995, 48, 63-71. [CrossRef] [PubMed]

34. Tsong, T.Y. Electroporation of Cell Membranes. Biophys. J. 1991, 60, 297-306. [CrossRef]

35. Chang, D.C. Structure and Dynamics of Electric Field-Induced Membrane Pores as Revealed by Rapid-Freezing Electron Microscopy; Academic Press, Inc.: Cambridge, MA, USA, 1992. [CrossRef]

36. Kinosita, K.; Hibino, M.; Itoh, H.; Shigemori, M.; Hirano, K.; Kirino, Y.; Hayakawa, T. Events of Membrane Electroporation Visualized on a Time Scale from Microsecond to Seconds; Elsevier Inc.: Amsterdam, The Netherlands, 1992. [CrossRef]

37. Marschall, A.L.J.; Zhang, C.; Frenzel, A.; Schirrmann, T.; Hust, M.; Perez, F.; Dübel, S. Delivery of Antibodies to the Cytosol: Debunking the Myths. MAbs 2014, 6, 943-956. [CrossRef]

38. Rubinsky, B. Irreversible Electroporation in Medicine. Technol. Cancer Res. Treat. 2007, 6, 255-259. [CrossRef]

39. Sherba, J.J.; Hogquist, S.; Lin, H.; Shan, J.W.; Shreiber, D.I.; Zahn, J.D. The Effects of Electroporation Buffer Composition on Cell Viability and Electro-Transfection Efficiency. Sci. Rep. 2020, 10, 1-9. [CrossRef]

40. Tirlapur, U.K.; König, K. Targeted Transfection by Femtosecond Laser. Nature 2001, 418, 290-291. [CrossRef]

41. Stevenson, D.; Agate, B.; Tsampoula, X.; Fischer, P.; Brown, C.T.A.; Sibbett, W.; Riches, A.; Gunn-Moore, F.; Dholakia, K. Femtosecond Optical Transfection of Cells:Viability and Efficiency. Opt. Express 2006, 14, 7125. [CrossRef]

42. Lapotko, D. Optical Excitation and Detection of Vapor Bubbles around Plasmonic Nanoparticles. Opt. Express 2009, 17, 2538. [CrossRef]

43. Lukianova-Hleb, E.; Hu, Y.; Latterini, L.; Tarpani, L.; Lee, S.; Drezek, R.A.; Hafner, J.H.; Lapotko, D.O. Plasmonic Nanobubbles as Transient Vapor Nanobubbles Generated around Plasmonic Nanoparticles. ACS Nano 2010, 4, 2109-2123. [CrossRef] [PubMed]

44. Qin, Z.; Bischof, J.C. Thermophysical and Biological Responses of Gold Nanoparticle Laser Heating. Chem. Soc. Rev. 2012, 41, 1191-1217. [CrossRef] [PubMed]

45. Xiong, R.; Drullion, C.; Verstraelen, P.; Demeester, J.; Skirtach, A.G.; Abbadie, C.; De Vos, W.H.; De Smedt, S.C.; Braeckmans, K. Fast Spatial-Selective Delivery into Live Cells. J. Control. Release 2017, 266, 198-204. [CrossRef] [PubMed]

46. Liu, J.; Xiong, R.; Brans, T.; Lippens, S.; Parthoens, E.; Zanacchi, F.C.; Magrassi, R.; Singh, S.K.; Kurungot, S.; Szunerits, S.; et al. Repeated Photoporation with Graphene Quantum Dots Enables Homogeneous Labeling of Live Cells with Extrinsic Markers for Fluorescence Microscopy. Light Sci. Appl. 2018, 7. [CrossRef] [PubMed]

47. Liu, J.; Hebbrecht, T.; Brans, T.; Parthoens, E.; Lippens, S.; Li, C.; De Keersmaecker, H.; De Vos, W.H.; De Smedt, S.C.; Boukherroub, R.; et al. Long-Term Live-Cell Microscopy with Labeled Nanobodies Delivered by Laser-Induced Photoporation. Nano Res. 2020, 13, 485-495. [CrossRef] [PubMed]

48. Frankel, A.D.; Pabo, C.O. Cellular Uptake of the Tat Protein from Human Immunodeficiency Virus. Cell 1988, 55, 1189-1193. [CrossRef]

49. Green, M.; Loewenstein, P.M. Autonomous Functional Domains of Chemically Synthesized Human Immunodeficiency Virus Tat Trans-Activator Protein. Cell 1988, 55, 1179-1188. [CrossRef]

50. Fawell, S.; Seery, J.; Daikh, Y.; Moore, C.; Chen, L.L.; Pepinsky, B.; Barsoum, J. Tat-Mediated Delivery of Heterologous Proteins into Cells. Proc. Natl. Acad. Sci. USA 1994, 91, 664-668. [CrossRef] 
51. Agrawal, P.; Bhalla, S.; Usmani, S.S.; Singh, S.; Chaudhary, K.; Raghava, G.P.S.; Gautam, A. CPPsite 2.0: A Repository of Experimentally Validated Cell-Penetrating Peptides. Nucleic Acids Res. 2016, 44, D1098-D1103. [CrossRef]

52. Lundberg, M.; Wikström, S.; Johansson, M. Cell Surface Adherence and Endocytosis of Protein Transduction Domains. Mol. Ther. 2003, 8, 143-150. [CrossRef]

53. Richard, J.P.; Melikov, K.; Vives, E.; Ramos, C.; Verbeure, B.; Gait, M.J.; Chernomordik, L.V.; Lebleu, B. Cell-Penetrating Peptides: A Reevaluation of the Mechanism of Cellular Uptake. J. Biol. Chem. 2003, 278, 585-590. [CrossRef] [PubMed]

54. LeCher, J.C.; Nowak, S.J.; McMurry, J.L. Breaking in and Busting out: Cell-Penetrating Peptides and the Endosomal Escape Problem. Biomol. Concepts 2017, 8, 131-141. [CrossRef] [PubMed]

55. Glab-ampai, K.; Malik, A.A.; Chulanetra, M.; Thanongsaksrikul, J.; Thueng-in, K.; Srimanote, P.; Tongtawe, P.; Chaicumpa, W. Inhibition of HCV Replication by Humanized-Single Domain Transbodies to NS4B. Biochem. Biophys. Res. Commun. 2016, 476, 654-664. [CrossRef] [PubMed]

56. Herce, H.D.; Schumacher, D.; Schneider, A.F.L.; Ludwig, A.K.; Mann, F.A.; Fillies, M.; Kasper, M.A.; Reinke, S.; Krause, E.; Leonhardt, H.; et al. Cell-Permeable Nanobodies for Targeted Immunolabelling and Antigen Manipulation in Living Cells. Nat. Chem. 2017, 9, 762-771. [CrossRef] [PubMed]

57. van Lith, S.A.M.; van den Brand, D.; Wallbrecher, R.; Wübbeke, L.; van Duijnhoven, S.M.J.; Mäkinen, P.I.; Hoogstad-van Evert, J.S.; Massuger, L.; Ylä-Herttuala, S.; Brock, R.; et al. The Effect of Subcellular Localization on the Efficiency of EGFR-Targeted VHH Photosensitizer Conjugates. Eur. J. Pharm. Biopharm. 2018, 124, 63-72. [CrossRef] [PubMed]

58. Tabtimmai, L.; Suphakun, P.; Srisook, P.; Kiriwan, D.; Phanthong, S.; Kiatwuthinon, P.; Chaicumpa, W.; Choowongkomon, K. Cell-Penetrable Nanobodies (Transbodies) That Inhibit the Tyrosine Kinase Activity of EGFR Leading to the Impediment of Human Lung Adenocarcinoma Cell Motility and Survival. J. Cell. Biochem. 2019, 120, 18077-18087. [CrossRef] [PubMed]

59. Derakhshankhah, H.; Jafari, S. Biomedicine \& Pharmacotherapy Cell Penetrating Peptides: A Concise Review with Emphasis on Biomedical Applications. Biomed. Pharmacother. 2018, 108, 1090-1096. [CrossRef]

60. Habault, J.; Poyet, J.L. Recent Advances in Cell Penetrating Peptide-Based Anticancer Therapies. Molecules 2019, 24, 927. [CrossRef]

61. Kamada, H.; Okamoto, T.; Kawamura, M.; Shibata, H.; Abe, Y.; Ohkawa, A.; Nomura, T.; Sato, M.; Mukai, Y.; Sugita, T.; et al. Creation of Novel Cell-Penetrating Peptides for Intracellular Drug Delivery Using Systematic Phage Display Technology Originated from Tat Transduction Domain. Biol. Pharm. Bull. 2007, 30, 218-223. [CrossRef]

62. Thompson, D.B.; Cronican, J.J.; Liu, D.R. Engineering and Identifying Supercharged Proteins for Macromolecule Delivery into Mammalian Cells, 1st ed.; Elsevier Inc.: Amsterdam, The Netherlands, 2012; Volume 503. [CrossRef]

63. Pardridge, W.M.; Kang, Y.-S.; Yang, J.; Buciak, J.L. Enhanced Cellular Uptake and in Vivo Biodistribution of a Monoclonal Antibody Following Cationization. J. Pharm. Sci. 1995, 84, 943-948. [CrossRef]

64. Cronican, J.J.; Thompson, D.B.; Beier, K.T.; McNaughton, B.R.; Cepko, C.L.; Liu, D.R. Potent Delivery of Functional Proteins into Mammalian Cells in Vitro and in Vivo Using a Supercharged Protein. ACS Chem. Biol. 2010, 5, 747-752. [CrossRef] [PubMed]

65. Bruce, V.J.; Lopez-islas, M.; Mcnaughton, B.R. Resurfaced Cell-Penetrating Nanobodies: A Potentially General Scaffold for Intracellularly Targeted Protein Discovery. Protein Sci. 2016, 25, 1129-1137. [CrossRef] [PubMed]

66. Rothbauer, U.; Zolghadr, K.; Tillib, S.; Nowak, D.; Schermelleh, L.; Gahl, A.; Backmann, N.; Conrath, K.; Muyldermans, S.; Cardoso, M.C.; et al. Targeting and Tracing Antigens in Live Cells with Fluorescent Nanobodies. Nat. Methods 2006, 3, 887-889. [CrossRef] [PubMed]

67. Pardi, N.; Secreto, A.J.; Shan, X.; Debonera, F.; Glover, J.; Yi, Y.; Muramatsu, H.; Ni, H.; Mui, B.L.; Tam, Y.K.; et al. Administration of Nucleoside-Modified MRNA Encoding Broadly Neutralizing Antibody Protects Humanized Mice from HIV-1 Challenge. Nat. Commun. 2017, 8. [CrossRef]

68. Tiwari, P.M.; Vanover, D.; Lindsay, K.E.; Bawage, S.S.; Kirschman, J.L.; Bhosle, S.; Li, A.W.; Zurla, C.; Santangelo, P.J. Engineered MRNA-Expressed Antibodies Prevent Respiratory Syncytial Virus Infection. Nat. Commun. 2018, 9. [CrossRef] 
69. Stadler, C.R.; Bähr-mahmud, H.; Celik, L.; Hebich, B.; Roth, A.S.; Roth, R.P.; Karikó, K.; Türeci, Ö.; Sahin, U. Elimination of Large Tumors in Mice by MRNA-Encoded Bispecific Antibodies. Nat. Med. 2017, 23, 815-820. [CrossRef]

70. Zhou, X.; Hao, R.; Chen, C.; Su, Z.; Zhao, L.; Luo, Z.; Xie, W. Rapid Delivery of Nanobodies/VHHs into Living Cells via Expressing In Vitro-Transcribed MRNA. Mol. Ther. Methods Clin. Dev. 2020, 17, 401-408. [CrossRef]

71. Schmidt, F.I.; Hanke, L.; Morin, B.; Brewer, R.; Brusic, V.; Whelan, S.P.J.; Ploegh, H.L. Phenotypic Lentivirus Screens to Identify Functional Single Domain Antibodies. Nat. Mircobiol. 2016, 1, 1680. [CrossRef]

72. Liu, Z.H.; Lei, K.X.; Han, G.W.; Xu, H.L.; He, F. Novel Lentivirus-Based Method for Rapid Selection of Inhibitory Nanobody against PRRSV. Viruses 2020, 12, 229. [CrossRef]

73. Duan, D. Systemic Delivery of Adeno-Associated Viral Vectors. Curr. Opin. Virol. 2016, 21, 16-25. [CrossRef]

74. Li, T.; Shen, Y.; Lin, F.; Fu, W.; Liu, S.; Wang, C.; Liang, J.; Fan, X.; Ye, X.; Tang, Y.; et al. Targeting RyR2 with a Phosphorylation Site-Specific Nanobody Reverses Dysfunction of Failing Cardiomyocytes in Rats. FASEB J. 2019, 33, 7467-7478. [CrossRef] [PubMed]

75. Louis Jeune, V.; Joergensen, J.A.; Hajjar, R.J.; Weber, T. Pre-Existing Anti-Adeno-Associated Virus Antibodies as a Challenge in AAV Gene Therapy. Hum. Gene Ther. Methods 2013, 24, 59-67. [CrossRef] [PubMed]

76. Administration U.S. Food \& Drug. Drugs@FDA: FDA-Approved Drugs. Available online: https://www. accessdata.fda.gov/scripts/cder/daf/ (accessed on 10 December 2020).

77. Farid, S.S. Process Economics of Industrial Monoclonal Antibody Manufacture. J. Chromatogr. B Anal. Technol. Biomed. Life Sci. 2007, 848, 8-18. [CrossRef] [PubMed]

78. De Marco, A. Recombinant Expression of Nanobodies and Nanobody-Derived Immunoreagents. Protein Expr. Purif. 2020, 172, 105645. [CrossRef]

79. De Vlieger, D.; Ballegeer, M.; Rossey, I.; Schepens, B.; Saelens, X. Single-Domain Antibodies and Their Formatting to Combat Viral Infections. Antibodies 2018, 8, 1. [CrossRef]

80. Scully, M.; Cataland, S.R.; Peyvandi, F.; Coppo, P.; Knöl, P.; Kremer Hovinga, J.A.; Metjian, A.; De La Rubia, J.; Pavenski, K.; Callewaert, F.; et al. Caplacizumab Treatment for Acquired Thrombotic Thrombocytopenic Purpura. N. Engl. J. Med. 2019, 380, 335-346. [CrossRef]

81. Kijanka, M.; Dorresteijn, B.; Oliveira, S.; Van Bergen En Henegouwen, P.M.P. Nanobody-Based Cancer Therapy of Solid Tumors. Nanomedicine 2015, 10, 161-174. [CrossRef]

82. Mendelsohn, J.; Baselga, J. Epidermal Growth Factor Receptor Targeting in Cancer. Semin. Oncol. 2006, 33, 369-385. [CrossRef]

83. Ferguson, F.M.; Gray, N.S. Kinase Inhibitors: The Road Ahead. Nat. Rev. Drug Discov. 2018, 17, $353-376$. [CrossRef]

84. Kanthala, S.; Pallerla, S.; Jois, S. Current and Future Targeted Therapies for Non-Small-Cell Lung Cancers with Aberrant EGF Receptors. Future Oncol. 2015, 11, 865-878. [CrossRef]

85. Roovers, R.C.; Laeremans, T.; Huang, L.; De Taeye, S.; Verkleij, A.J.; Revets, H.; De Haard, H.J.; Van Bergen En Henegouwen, P.M.P. Efficient Inhibition of EGFR Signalling and of Tumour Growth by Antagonistic Anti-EGFR Nanobodies. Cancer Immunol. Immunother. 2007, 56, 303-317. [CrossRef] [PubMed]

86. Jin, X.; Dai, L.; Ma, Y.; Wang, J.; Liu, Z. Implications of HIF-1 $\alpha$ in the Tumorigenesis and Progression of Pancreatic Cancer. Cancer Cell Int. 2020, 20, 1-11. [CrossRef] [PubMed]

87. Zhao, X.; Li, F.; Li, Y.; Wang, H.; Ren, H.; Chen, J.; Nie, G.; Hao, J. Co-Delivery of HIF1 $\alpha$ SiRNA and Gemcitabine via Biocompatible Lipid-Polymer Hybrid Nanoparticles for Effective Treatment of Pancreatic Cancer. Biomaterials 2015, 46, 13-25. [CrossRef] [PubMed]

88. Li, M.; Xie, H.; Liu, Y.; Xia, C.; Cun, X.; Long, Y.; Chen, X.; Deng, M.; Guo, R.; Zhang, Z.; et al. Knockdown of Hypoxia-Inducible Factor-1 Alpha by Tumor Targeted Delivery of CRISPR/Cas9 System Suppressed the Metastasis of Pancreatic Cancer. J. Control. Release 2019, 304, 204-215. [CrossRef] [PubMed]

89. Yu, T.; Tang, B.; Sun, X. Development of Inhibitors Targeting Hypoxia-Inducible Factor 1 and 2 for Cancer Therapy. Yonsei Med. J. 2017, 58, 489-496. [CrossRef] [PubMed]

90. Wilbie, D.; Walther, J.; Mastrobattista, E. Delivery Aspects of CRISPR/Cas for in Vivo Genome Editing. Acc. Chem. Res. 2019, 52, 1555-1564. [CrossRef]

91. Hu, M.; Kang, G.; Cheng, X.; Wang, J.; Li, R.; Bai, Z.; Yang, D.; Huang, H. In Vitro Affinity Maturation to Improve the Efficacy of a Hypoxia-Inducible Factor $1 \alpha$ Single-Domain Intrabody. Biochem. Biophys. Res. Commun. 2020, 529, 936-942. [CrossRef] 
92. Ingelsson, M. Alpha-Synuclein Oligomers-Neurotoxic Molecules in Parkinson's Disease and Other Lewy Body Disorders. Front. Neurosci. 2016, 10, 1-10. [CrossRef]

93. Guilliams, T.; El-Turk, F.; Buell, A.K.; O’Day, E.M.; Aprile, F.A.; Esbjörner, E.K.; Vendruscolo, M.; Cremades, N.; Pardon, E.; Wyns, L.; et al. Nanobodies Raised against Monomeric $\alpha$-Synuclein Distinguish between Fibrils at Different Maturation Stages. J. Mol. Biol. 2013, 425, 2397-2411. [CrossRef]

94. Iljina, M.; Hong, L.; Horrocks, M.H.; Ludtmann, M.H.; Choi, M.L.; Hughes, C.D.; Ruggeri, F.S.; Guilliams, T.; Buell, A.K.; Lee, J.E.; et al. Nanobodies Raised against Monomeric $\alpha$-Synuclein Inhibit Fibril Formation and Destabilize Toxic Oligomeric Species. BMC Biol. 2017, 15, 1-14. [CrossRef]

95. Butler, D.C.; Joshi, S.N.; De Genst, E.; Baghel, A.S.; Dobson, C.M.; Messer, A. Bifunctional Anti-Non-Amyloid Component $\alpha$-Synuclein Nanobodies Are Protective in Situ. PLoS ONE 2016, 11. [CrossRef]

96. Chatterjee, D.; Bhatt, M.; Butler, D.; De Genst, E.; Dobson, C.M.; Messer, A.; Kordower, J.H. Proteasome-Targeted Nanobodies Alleviate Pathology and Functional Decline in an $\alpha$-Synuclein-Based Parkinson's Disease Model. NPJ Park. Dis. 2018, 4, 1-10. [CrossRef]

97. Kiuru-Enari, S.; Haltia, M. Hereditary Gelsolin Amyloidosis, 1st ed.; Elsevier: Amsterdam, The Netherlands, 2013; Volume 115. [CrossRef]

98. Verhelle, A.; Nair, N.; Everaert, I.; Van Overbeke, W.; Supply, L.; Zwaenepoel, O.; Peleman, C.; Van Dorpe, J.; Lahoutte, T.; Devoogdt, N.; et al. AAV9 Delivered Bispecific Nanobody Attenuates Amyloid Burden in the Gelsolin Amyloidosis Mouse Model. Hum. Mol. Genet. 2017, 26, 1353-1364. [CrossRef]

99. Kvisgaard, L.K.; Kristensen, C.S.; Ryt-Hansen, P.; Pedersen, K.; Stadejek, T.; Trebbien, R.; Andresen Lo, L.O.; Larsen, L.E. A Recombination between Two Type 1 Porcine Reproductive and Respiratory Syndrome Virus (PRRSV-1) Vaccine Strains Has Caused Severe Outbreaks in Danish Pigs. Transbound. Emerg. Dis. 2020, 1786-1796. [CrossRef] [PubMed]

100. Zhang, Z.; Qu, X.; Zhang, H.; Tang, X.; Bian, T.; Sun, Y.; Zhou, M.; Ren, F.; Wu, P. Evolutionary and Recombination Analysis of Porcine Reproductive and Respiratory Syndrome Isolates in China. Virus Genes 2020. [CrossRef] [PubMed]

101. Saenglub, W.; Jantafong, T.; Mungkundar, C.; Romlamduan, N.; Pinitkiatisakul, S.; Lekcharoensuk, P. Genetic Signatures of the Immune-Escaping Type 2 Porcine Reproductive and Respiratory Syndrome Virus in Farms with a Robust Vaccination Program. Microb. Pathog. 2020, 144, 104166. [CrossRef] [PubMed]

102. Han, J.; Zhou, L.; Ge, X.; Guo, X.; Yang, H. Pathogenesis and Control of the Chinese Highly Pathogenic Porcine Reproductive and Respiratory Syndrome Virus. Vet. Microbiol. 2017, 209, 30-47. [CrossRef] [PubMed]

103. Liu, H.; Liang, C.; Duan, H.; Zhang, X.; Wang, X.; Xiao, S.; Zhou, E.M. Intracellularly Expressed Nanobodies against Non-Structural Protein 4 of Porcine Reproductive and Respiratory Syndrome Virus Inhibit Virus Replication. Biotechnol. Lett. 2016, 38, 1081-1088. [CrossRef]

104. Liu, H.; Wang, Y.; Duan, H.; Zhang, A.; Liang, C.; Gao, J.; Zhang, C.; Huang, B.; Li, Q.; Li, N.; et al. An Intracellularly Expressed Nsp9-Specific Nanobody in MARC-145 Cells Inhibits Porcine Reproductive and Respiratory Syndrome Virus Replication. Vet. Microbiol. 2015, 181, 252-260. [CrossRef]

105. Wang, L.; Zhang, L.; Huang, B.; Li, K.; Hou, G.; Zhao, Q.; Wu, C.; Nan, Y.; Du, T.; Mu, Y.; et al. A Nanobody Targeting Viral Nonstructural Protein 9 Inhibits Porcine Reproductive and Respiratory Syndrome Virus Replication. J. Virol. 2019, 93, 1-15. [CrossRef]

106. Pinior, B.; Garcia, S.; Minviel, J.J.; Raboisson, D. Epidemiological Factors and Mitigation Measures Influencing Production Losses in Cattle Due to Bovine Viral Diarrhoea Virus Infection: A Meta-Analysis. Transbound. Emerg. Dis. 2019, 66, 2426-2439. [CrossRef] [PubMed]

107. Duan, H.; Ma, Z.; Xu, L.; Zhang, A.; Li, Z.; Xiao, S. A Novel Intracellularly Expressed NS5B-Specific Nanobody Suppresses Bovine Viral Diarrhea Virus Replication. Vet. Microbiol. 2020, 240, 108449. [CrossRef] [PubMed]

108. Verheesen, P.; de Kluijver, A.; van Koningsbruggen, S.; de Brij, M.; de Haard, H.J.; van Ommen, G.J.B.; van der Maarel, S.M.; Verrips, C.T. Prevention of Oculopharyngeal Muscular Dystrophy-Associated Aggregation of Nuclear Poly(A)-Binding Protein with a Single-Domain Intracellular Antibody. Hum. Mol. Genet. 2006, 15, 105-111. [CrossRef] [PubMed]

109. Chartier, A.; Raz, V.; Sterrenburg, E.; Verrips, C.T.; van der Maarel, S.M.; Simonelig, M. Prevention of Oculopharyngeal Muscular Dystrophy by Muscular Expression of Llama Single-Chain Intrabodies in Vivo. Hum. Mol. Genet. 2009, 18, 1849-1859. [CrossRef] 
110. Gueorguieva, D.; Li, S.; Walsh, N.; Mukerji, A.; Tanha, J.; Pandey, S.; Gueorguieva, D.; Li, S.; Walsh, N.; Mukerji, A.; et al. Identification of Single-domain, Bax-specific Intrabodies That Confer Resistance to Mammalian Cells against Oxidative-stress-induced Apoptosis. FASEB J. 2006, 20, 2636-2638. [CrossRef]

111. Van Overbeke, W.; Wongsantichon, J.; Everaert, I.; Verhelle, A.; Zwaenepoel, O.; Loonchanta, A.; Burtnick, L.D.; De Ganck, A.; Hochepied, T.; Haigh, J.; et al. An ER-Directed Gelsolin Nanobody Targets the First Step in Amyloid Formation in a Gelsolin Amyloidosis Mouse Model. Hum. Mol. Genet. 2015, 24, 2492-2507. [CrossRef]

112. Vercruysse, T.; Pardon, E.; Vanstreels, E.; Steyaert, J.; Daelemans, D. An Intrabody Based on a Llama Single-Domain Antibody Targeting the N-Terminal $\alpha$-Helical Multimerization Domain of HIV-1 Rev Prevents Viral Production. J. Biol. Chem. 2010, 285, 21768-21780. [CrossRef]

113. Boons, E.; Li, G.; Vanstreels, E.; Vercruysse, T.; Pannecouque, C.; Vandamme, A.M.; Daelemans, D. A Stably Expressed Llama Single-Domain Intrabody Targeting Rev Displays Broad-Spectrum Anti-HIV Activity. Antivir. Res. 2014, 112, 91-102. [CrossRef]

114. Bouchet, J.; Basmaciogullari, S.E.; Chrobak, P.; Stolp, B.; Bouchard, N.; Fackler, O.T.; Chames, P.; Jolicoeur, P.; Benichou, S.; Baty, D. Inhibition of the Nef Regulatory Protein of HIV-1 by a Single-Domain Antibody. Blood 2011, 117, 3559-3568. [CrossRef]

115. Pellis, M.; Pardon, E.; Zolghadr, K.; Rothbauer, U.; Vincke, C.; Kinne, J.; Dierynck, I.; Hertogs, K.; Leonhardt, H.; Messens, J.; et al. A Bacterial-Two-Hybrid Selection System for One-Step Isolation of Intracellularly Functional Nanobodies. Arch. Biochem. Biophys. 2012, 526, 114-123. [CrossRef]

116. Thueng-in, K.; Thanongsaksrikul, J.; Srimanote, P.; Bangphoomi, K.; Poungpair, O.; Maneewatch, S.; Choowongkomon, K.; Chaicumpa, W. Cell Penetrable Humanized-VH/VHH That Inhibit RNA Dependent RNA Polymerase (NS5B) of HCV. PLoS ONE 2012, 7. [CrossRef] [PubMed]

117. Jittavisutthikul, S.; Thanongsaksrikul, J.; Thueng-In, K.; Chulanetra, M.; Srimanote, P.; Seesuay, W.; Malik, A.A.; Chaicumpa, W. Humanized-VHH Transbodies That Inhibit HCV Protease and Replication. Viruses 2015, 7, 2030-2056. [CrossRef] [PubMed]

118. Phalaphol, A.; Thueng-in, K.; Thanongsaksrikul, J.; Poungpair, O.; Bangphoomi, K.; Sookrung, N.; Srimanote, P.; Chaicumpa, W. Humanized-VH/VHH That Inhibit HCV Replication by Interfering with the Virus Helicase Activity. J. Virol. Methods 2013, 194, 289-299. [CrossRef] [PubMed]

119. Serruys, B.; van Houtte, F.; Verbrugghe, P.; Leroux-Roels, G.; Vanlandschoot, P. Llama-Derived Single-Domain Intrabodies Inhibit Secretion of Hepatitis B Virions in Mice. Hepatology 2009, 49, 39-49. [CrossRef]

120. Herrera, C.; Tremblay, J.M.; Shoemaker, C.B.; Mantis, N.J. Mechanisms of Ricin Toxin Neutralization Revealed through Engineered Homodimeric and Heterodimeric Camelid Antibodies. J. Biol. Chem. 2015, 290, 27880-27889. [CrossRef]

121. Herrera, C.; IreneKlokk, T.; Cole, R.; Sandvig, K.; Mantis, N.J. A Bispecific Antibody Promotes Aggregation of Ricin Toxin on Cell Surfaces and Alters Dynamics of Toxin Internalization and Trafficking. PLoS ONE 2016, 11, e0156893. [CrossRef]

122. Alzogaray, V.; Danquah, W.; Aguirre, A.; Urrutia, M.; Berguer, P.; Véscovi, E.G.; Haag, F.; Koch-Nolte, F.; Goldbaum, F.A. Single-Domain Llama Antibodies as Specific Intracellular Inhibitors of SpvB, the Actin ADP-Ribosylating Toxin of Salmonella Typhimurium. FASEB J. 2011, 25, 526-534. [CrossRef]

123. Tremblay, J.M.; Kuo, C.L.; Abeijon, C.; Sepulveda, J.; Oyler, G.; Hu, X.; Jin, M.M.; Shoemaker, C.B. Camelid Single Domain Antibodies (VHHs) as Neuronal Cell Intrabody Binding Agents and Inhibitors of Clostridium Botulinum Neurotoxin (BoNT) Proteases. Toxicon 2010, 56, 990-998. [CrossRef]

124. Kuo, C.L.; Oyler, G.A.; Shoemaker, C.B. Accelerated Neuronal Cell Recovery from Botulinum Neurotoxin Intoxication by Targeted Ubiquitination. PLOS ONE 2011, 6. [CrossRef]

125. Yu, D.; Lee, H.; Hong, J.; Jung, H.; Jo, Y.J.; Oh, B.H.; Park, B.O.; Do Heo, W. Optogenetic Activation of Intracellular Antibodies for Direct Modulation of Endogenous Proteins. Nat. Methods 2019, 16, 1095-1100. [CrossRef]

126. Bertier, L.; Boucherie, C.; Zwaenepoel, O.; Vanloo, B.; Van Troys, M.; Van Audenhove, I.; Gettemans, J. Inhibitory Cortactin Nanobodies Delineate the Role of NTA- and SH3-Domain-Specific Functions during Invadopodium Formation and Cancer Cell Invasion. FASEB J. 2017, 31, 2460-2476. [CrossRef] [PubMed]

127. Rotty, J.D.; Wu, C.; Bear, J.E. New Insights into the Regulation and Cellular Functions of the ARP2/3 Complex. Nat. Rev. Mol. Cell Biol. 2013, 14, 7-12. [CrossRef] [PubMed] 
128. Izdebska, M.; Zielińska, W.; Grzanka, D.; Gagat, M. The Role of Actin Dynamics and Actin-Binding Proteins Expression in Epithelial-to-Mesenchymal Transition and Its Association with Cancer Progression and Evaluation of Possible Therapeutic Targets. Biomed. Res. Int. 2018, 2018. [CrossRef] [PubMed]

129. Jang, H.I.; Wilson, P.G.; Sau, M.; Chawla, U.; Rodgers, D.W.; Galperin, E. Single-Domain Antibodies for Functional Targeting of the Signaling Scaffold Shoc2. Mol. Immunol. 2020, 118, 110-116. [CrossRef] [PubMed]

130. Gripp, K.W.; Zand, D.J.; Demmer, L.; Anderson, C.E.; Dobyns, W.B.; Zackai, E.H.; Denenberg, E.; Jenny, K.; Stabley, D.L.; Sol-Church, K. Expanding the SHOC2 Mutation Associated Phenotype of Noonan Syndrome with Loose Anagen Hair: Structural Brain Anomalies and Myelofibrosis. Am. J. Med. Genet. Part A 2013, 161, 2420-2430. [CrossRef]

131. Tome-Amat, J.; Ramos, I.; Amanor, F.; Fernández-Sesma, A.; Ashour, J. Influenza A Virus Utilizes Low Affinity, High Avidity Interactions with the Nuclear Import Machinery to Ensure Infection and Immune Evasion. J. Virol. 2018. [CrossRef]

132. Ashour, J.; Schmidt, F.I.; Hanke, L.; Cragnolini, J.J.; Cavallari, M.; Altenburg, A.; Brewer, R.C.; Ingram, J.R.; Shoemaker, C.; Ploegh, H.L. Intracellular Expression of Camelid Single-Domain Antibodies Specific for Influenza Virus Nucleoprotein Uncovers Distinct Features of Its Nuclear Localization. J. Virol. 2015, 89, 2792-2800. [CrossRef]

133. Bjarnadóttir, T.K.; Gloriam, D.E.; Hellstrand, S.H.; Kristiansson, H.; Fredriksson, R.; Schiöth, H.B. Comprehensive Repertoire and Phylogenetic Analysis of the G Protein-Coupled Receptors in Human and Mouse. Genomics 2006, 88, 263-273. [CrossRef]

134. Farrants, H.; Gutzeit, V.A.; Acosta-Ruiz, A.; Trauner, D.; Johnsson, K.; Levitz, J.; Broichhagen, J. SNAP-Tagged Nanobodies Enable Reversible Optical Control of a G Protein-Coupled Receptor via a Remotely Tethered Photoswitchable Ligand. ACS Chem. Biol. 2018, 13, 2682-2688. [CrossRef]

135. Bery, N.; Keller, L.; Soulié, M.; Gence, R.; Iscache, A.L.; Cherier, J.; Cabantous, S.; Sordet, O.; Lajoie-Mazenc, I.; Pedelacq, J.D.; et al. A Targeted Protein Degradation Cell-Based Screening for Nanobodies Selective toward the Cellular RHOB GTP-Bound Conformation. Cell Chem. Biol. 2019, 26, 1544-1558.e6. [CrossRef]

136. Etienne-Manneville, S.; Hall, A. Rho GTPases in Cancer Cell Biology. Nature 2002, 450, 629-635. [CrossRef] [PubMed]

137. Vega, F.M.; Ridley, A.J. The RhoB Small GTPase in Physiology and Disease. Small GTPases 2018, 9, $384-393$. [CrossRef] [PubMed]

138. Mallery, D.L.; McEwan, W.A.; Bidgood, S.R.; Towers, G.J.; Johnson, C.M.; James, L.C. Antibodies Mediate Intracellular Immunity through Tripartite Motif-Containing 21 (TRIM21). Proc. Natl. Acad. Sci. USA 2010, 107, 19985-19990. [CrossRef] [PubMed]

139. Clift, D.; McEwan, W.A.; Labzin, L.I.; Konieczny, V.; Mogessie, B.; James, L.C.; Schuh, M. A Method for the Acute and Rapid Degradation of Endogenous Proteins. Cell 2017, 171, 1692-1706.e18. [CrossRef]

140. Van Audenhove, I.; Boucherie, C.; Pieters, L.; Zwaenepoel, O.; Vanloo, B.; Martens, E.; Verbrugge, C.; Hassanzadeh-Ghassabeh, G.; Vandekerckhove, J.; Cornelissen, M.; et al. Stratifying Fascin and Cortactin Function in Invadopodium Formation Using Inhibitory Nanobodies and Targeted Subcellular Delocalization. FASEB J. 2014, 28, 1805-1818. [CrossRef]

141. Beghein, E.; Van Audenhove, I.; Zwaenepoel, O.; Verhelle, A.; De Ganck, A.; Gettemans, J. A New Survivin Tracer Tracks, Delocalizes and Captures Endogenous Survivin at Different Subcellular Locations and in Distinct Organelles. Sci. Rep. 2016, 6, 11-15. [CrossRef]

142. Steels, A.; Verhelle, A.; Zwaenepoel, O.; Gettemans, J. Intracellular Displacement of P53 Using Transactivation Domain (P53 TAD) Specific Nanobodies. MAbs 2018, 10, 1045-1059. [CrossRef]

143. Traub, L.M. A Nanobody-Based Molecular Toolkit Provides New Mechanistic Insight into Clathrin-Coat Initiation. Elife 2019, 8, 1-42. [CrossRef]

144. Prole, D.L.; Taylor, C.W. A Genetically Encoded Toolkit of Functionalized Nanobodies against Fluorescent Proteins for Visualizing and Manipulating Intracellular Signalling. BMC Biol. 2019, 17, 1-24. [CrossRef]

145. Yamashita, N.; Tokunaga, E.; Kitao, H.; Hisamatsu, Y. Vimentin as a Poor Prognostic Factor for Triple-Negative Breast Cancer. J. Cancer Res. Clin. Oncol. 2013, 139, 739-746. [CrossRef]

146. Richardson, A.M.; Havel, L.S.; Koyen, A.E.; Konen, J.M.; Shupe, J.; Iv, W.G.W.; Martin, W.D.; Grossniklaus, H.E.; Sica, G.; Gilbert-ross, M.; et al. Vimentin Is Required for Lung Adenocarcinoma Metastasis via Heterotypic Tumor Cell-Cancer- Associated Fibroblast Interactions during Collective Invasion. Clin. Cancer Res. 2017, 1-14. [CrossRef] [PubMed] 
147. Maier, J.; Traenkle, B.; Rothbauer, U. Real-Time Analysis of Epithelial- Mesenchymal Transition Using Fluorescent Single-Domain Antibodies. Sci. Rep. 2015, 5. [CrossRef] [PubMed]

148. Maier, J.; Traenkle, B.; Rothbauer, U. Visualizing Epithelial-Mesenchymal Transition Using the Chromobody Technology. Cancer Res. 2016, 76, 5592-5596. [CrossRef] [PubMed]

149. Wegner, W.; Ilgen, P.; Gregor, C.; Van Dort, J.; Mott, A.C.; Steffens, H.; Willig, K.I. In Vivo Mouse and Live Cell STED Microscopy of Neuronal Actin Plasticity Using Far-Red Emitting Fluorescent Proteins. Sci. Rep. 2017, 7, 1-10. [CrossRef]

150. Periz, J.; Whitelaw, J.; Harding, C.; Gras, S.; Igor, M.; Rosario, D.; Latorre-barragan, F.; Lemgruber, L.; Reimer, M.A.; Insall, R.; et al. Toxoplasma Gondii F-Actin Forms an Extensive Filamentous Network Required for Material Exchange and Parasite Maturation. Elife 2017, 6, e24119. [CrossRef]

151. Stortz, J.F.; Del Rosario, M.; Singer, M.; Wilkes, J.M.; Meissner, M.; Das, S. Formin-2 Drives Polymerisation of Actin Filaments Enabling Segregation of Apicoplasts and Cytokinesis in Plasmodium Falciparum. Elife 2019, 8, 1-34. [CrossRef]

152. Tosetti, N.; Pacheco, N.D.S.; Favre, D.S.; Jacot, D. Three F-Actin Assembly Centers Regulate Organelle Inheritance, Cell-Cell Communication and Motility in Toxoplasma Gondii. Elife 2019, 8, 1-32. [CrossRef]

153. Keller, L.; Bery, N.; Tardy, C.; Ligat, L.; Favre, G.; Rabbitts, T.H.; Olichon, A. Selection and Characterization of a Nanobody Biosensor of GTP-Bound RHO Activities. Antibodies 2019, 8, 8. [CrossRef]

154. Lawson, C.D.; Ridley, A.J. Rho GTPase Signaling Complexes in Cell Migration and Invasion. J. Cell Biol. 2018, 217, 447-457. [CrossRef]

155. Keller, B.M.; Maier, J.; Secker, K.A.; Egetemaier, S.M.; Parfyonova, Y.; Rothbauer, U.; Traenkle, B. Chromobodies to Quantify Changes of Endogenous Protein Concentration in Living Cells. Mol. Cell. Proteom. 2018, 17, 2518-2533. [CrossRef]

156. Bachmair, A.; Finley, D.; Varshavsky, A. In Vivo Half-Life of a Protein Is a Function of Its Amino-Terminal Residue. Science (80-) 1986, 234, 179-186. [CrossRef] [PubMed]

157. Varshavsky, A. The N-End Rule Pathway and Regulation by Proteolysis. Protein Sci. 2011, 20, 1298-1345. [CrossRef] [PubMed]

158. Varshavsky, A. Ubiquitin Fusion Technique and Related Methods. Methods Enzymol. 2005, 399, 777-799. [CrossRef] [PubMed]

159. Keller, B.-M.; Maier, J.; Weldle, M.; Segan, S.; Traenkle, B.; Rothbauer, U. A Strategy to Optimize the Generation of Stable Chromobody Cell Lines for Visualization and Quantification of Endogenous Proteins in Living Cells. Antibodies 2019, 8, 10. [CrossRef]

160. Norrman, K.; Fischer, Y.; Bonnamy, B.; Sand, F.W.; Ravassard, P.; Semb, H. Quantitative Comparison of Constitutive Promoters in Human ES Cells. PLoS ONE 2010, 5. [CrossRef]

161. Kotin, R.M.; Linden, R.M.; Berns, K.I. Characterization of a Preferred Site on Human Chromosome 19q for Integration of Adeno-Associated Virus DNA by Non-Homologous Recombination. EMBO J. 1992, 11, 5071-5078. [CrossRef]

162. Sadelain, M.; Papapetrou, E.P.; Bushman, F.D. Safe Harbours for the Integration of New DNA in the Human Genome. Nat. Rev. Cancer 2012, 12, 51-58. [CrossRef]

163. Pleiner, T.; Bates, M.; Trakhanov, S.; Lee, C.T.; Schliep, J.E.; Chug, H.; Böhning, M.; Stark, H.; Urlaub, H.; Görlich, D. Nanobodies: Site-Specific Labeling for Super-Resolution Imaging, Rapid Epitope- Mapping and Native Protein Complex Isolation. Elife 2015, 4, 1-21. [CrossRef]

164. Hebbrecht, T.; Liu, J.; Zwaenepoel, O.; Boddin, G.; Van Leene, C.; Decoene, K.; Madder, A.; Braeckmans, K.; Gettemans, J. Nanobody Click Chemistry for Convenient Site-Specific Fluorescent Labelling, Single Step Immunocytochemistry and Delivery into Living Cells by Photoporation and Live Cell Imaging. N. Biotechnol. 2020, 59, 33-43. [CrossRef]

165. An, N.; Hou, Y.N.; Zhang, Q.X.; Li, T.; Zhang, Q.L.; Fang, C.; Chen, H.; Lee, H.C.; Zhao, Y.J.; Du, X. Anti-Multiple Myeloma Activity of Nanobody-Based Anti-CD38 Chimeric Antigen Receptor T Cells. Mol. Pharm. 2018, 15, 4577-4588. [CrossRef]

166. Sun, M.; Pace, C.S.; Yao, X.; Yu, F.; Padte, N.N.; Huang, Y.; Seaman, M.S.; Li, Q.; Ho, D.D. Rational Design and Characterization of the Novel, Broad and Potent Bispecific HIV-1 Neutralizing Antibody IMabm36. J. Acquir. immune Defic. Syndr. 2014, 66, 473-483. [CrossRef] [PubMed] 
167. Pardon, E.; Laeremans, T.; Triest, S.; Rasmussen, S.G.F.; Wohlkönig, A.; Ruf, A.; Muyldermans, S.; Hol, W.G.J.; Kobilka, B.K.; Steyaert, J. A General Protocol for the Generation of Nanobodies for Structural Biology. Nat. Protoc. 2014, 9, 674. [CrossRef] [PubMed]

168. Koch-nolte, F.; Reyelt, J.; Scho, B.; Schwarz, N.; Scheuplein, F.; Rothenburg, S.; Haag, F.; Alzogaray, V.; Cauerhff, A.; Goldbaum, F.A. Single Domain Antibodies from Llama Effectively and Specifically Block T Cell Ecto-ADP-Ribosyltransferase ART2. 2 in Vivo. FASEB J. 2007, 21, 3490-3498. [CrossRef] [PubMed]

169. Eden, T.; Menzel, S.; Wesolowski, J.; Bergmann, P.; Koch-nolte, F. A CDNA Immunization Strategy to Generate Nanobodies against Membrane Proteins in Native Conformation. Front. Immunol. 2018, 8, 1-13. [CrossRef] [PubMed]

170. Jähnichen, S.; Blanchetot, C.; Maussang, D.; Gonzalez-pajuelo, M.; Chow, K.Y. CXCR4 Nanobodies (VHH-Based Single Variable Domains) Potently Inhibit Chemotaxis and HIV-1 Replication and Mobilize Stem Cells. Proc. Natl. Acad. Sci. USA 2010, 107, 20565-20570. [CrossRef]

171. Muyldermans, S. Nanobodies: Natural Single-Domain Antibodies. Annu. Rev. Biochem. 2013, 82, $775-797$. [CrossRef]

172. Yan, J.; Wang, P.; Zhu, M.; Li, G.; Romão, E.; Xiong, S.; Wan, Y. Characterization and Applications of Nanobodies against Human Procalcitonin Selected from a Novel Naïve Nanobody Phage Display Library. J. Nanobiotechnol. 2015, 13, 1-11. [CrossRef]

173. Gene, R.W.; Kumaran, J.; Aroche, C.; van Faassen, H.; Hall, J.C.; MacKenzie, C.R.; Arbabi-Ghahroudi, M. High Affinity Anti-Internalin B VHH Antibody Fragments Isolated from Naturally and Artificially Immunized Repertoires. J. Immunol. Methods 2015, 416, 29-39. [CrossRef]

174. Moutel, S.; Bery, N.; Bernard, V.; Keller, L.; Lemesre, E.; De Marco, A.; Ligat, L.; Rain, J.C.; Favre, G.; Olichon, A.; et al. NaLi-H1: A Universal Synthetic Library of Humanized Nanobodies Providing Highly Functional Antibodies and Intrabodies. Elife 2016, 5, e16228. [CrossRef]

175. Fleetwood, F.; Devoogdt, N.; Pellis, M.; Wernery, U.; Lo, J. Surface Display of a Single-Domain Antibody Library on Gram-Positive Bacteria. Cell Mol. Life Sci. 2013, 1081-1093. [CrossRef]

176. Salema, V.; Fernández, L.Á. Escherichia Coli Surface Display for the Selection of Nanobodies. Microb. Biotechnol. 2017, 10, 1468-1484. [CrossRef] [PubMed]

177. Ryckaert, S.; Pardon, E.; Steyaert, J.; Callewaert, N. Isolation of Antigen-Binding Camelid Heavy Chain Antibody Fragments (Nanobodies) from an Immune Library Displayed on the Surface of Pichia Pastoris. J. Biotechnol. 2010, 145, 93-98. [CrossRef] [PubMed]

178. Bencurova, E.; Pulzova, L.; Flachbartova, Z.; Bhide, M. A Rapid and Simple Pipeline for Synthesis of MRNA-Ribosome-VHH Complexes Used in Single-Domain Antibody Ribosome Display. Mol. Biosyst. 2015, 11, 1515-1524. [CrossRef] [PubMed]

Publisher's Note: MDPI stays neutral with regard to jurisdictional claims in published maps and institutional affiliations.

(C) 2020 by the authors. Licensee MDPI, Basel, Switzerland. This article is an open access article distributed under the terms and conditions of the Creative Commons Attribution (CC BY) license (http://creativecommons.org/licenses/by/4.0/). 